\section{Sosyal Gelişme Endeksi Boyutları Arasındaki İlişkilerin Somer D Temelli DEMATEL Yöntemi ile Analizi}

\author{
Furkan Fahri Altintas ${ }^{\mathrm{a}}$
}

Öz: Ülkelerin Sosyal Gelişme Endeksi (SPI)'ni oluşturan boyutların ve bileşenlerin birbirlerini tamamlayıc faaliyet göstermeleri, ülkelerin sosyal gelişim performanslarının artmalarına sebep olabilmektedir. Bu kapsamda araştırmada, 2020 yılı için Avrupa Birliği ülkelerinin SPI bileşen değerleri kapsamında SPI boyutları arasındaki ilişkisel yapı incelenmiştir. Bulgulara göre, söz konusu ilişkisel yapıya en fazla katkı sağlayan, ilişkisel yapıda en fazla etkilenme ile en fazla ilişkisel yoğunluk değerine sahip olan SPI boyutunun "fırsatlar" olduğu tespit edilmiştir. Böylelikle "fırsatlar" boyutu diğer boyutlara kıyasla ilişkisel yapıda daha çok sebep ve sonuç özelliğine sahip olduğu değerlendirilmiştir. Diğer bir bulguya göre, ilişkisel yapıda "barınma" bileşeninin "etkileyen", diğer 11 bileşenin ise "etkilenen" niteliğine sahip olduğu tespit edilmiştir. Ayrıca, "temel insani gereksinimler" boyutu bileşenlerinin ilişki yapısı içinde diğer boyutların bileşenlerine kıyasla etkileme ve etkilenme değerleri arasındaki farkın daha az olduğu gözlenmiştir. Dolayısıyla ilişkisel yapıda "temel insan gereksinimleri" boyutu kendi ilişki kapasitesine göre diğer boyutlara kıyasla etkileme niteliğine daha yakın ve bağımsı değişken olma işlevselliğinin daha öncelikli olduğu sonucuna ulaşılmıştır.

\section{Analysis of the Relationships between Social Development Index Dimensions with Somers' D-Based DEMATEL Method}

Abstract: Complementary activities of the dimensions and components that make up the Social Development Index (SPI) of the countries can cause the social development performances of the countries to increase. In this context, the relational structure between the SPI dimensions within the scope of the SPI component values of the European Union countries for 2020 was examined. According to the findings, it was determined that the SPI dimension, which contributes the most to the relational structure in question and has the most relational density value with the most affected in the relational structure, is "opportunities". Thus, it was evaluated that the " opportunities "dimension had more cause and effect features in relational structure compared to other dimensions. According to another finding, in the relational structure, the "accommodation" component was found to have the "affecting" and the other 11 components "affected". In addition, it has been observed that the difference between the influence and the influence values of the "basic human needs" dimension components is less than the components of the other dimensions. Therefore, in the relational structure, it was concluded that the "basic human needs "dimension is closer to the influencing quality compared to other dimensions according to its own relational capacity, and the functionality of being an independent variable has priority.
Anahtar Sözcükler: Sosyal Gelişme, Sosyal Gelişme Endeksi, Somer D, DEMATEL

JEL: C44, C60, 100

$\begin{array}{ll}\text { Geliş } & : 21 \text { Aralık } 2020 \\ \text { Düzeltme } & : 09 \text { Mart } 2021 \\ \text { Kabul } & : \text { 31 Mart 2021 } \\ & \\ \text { Tür } & \text { : Araştırma }\end{array}$

Keywords: Social Development, Social Development Index, Somer's d, DEMATEL

JEL: C44, C60, 100

$\begin{array}{ll}\text { Received } & : 21 \text { December } 2020 \\ \text { Revised } & : 09 \text { March } 2021 \\ \text { Accepted } & : \text { 31 March } 2021 \\ \text { Type } & : \text { Research }\end{array}$




\section{Giriş}

Sosyal gelişme, bir toplumun bireylerinin temel anlamda öncelikli gereksinimlerini karşılamasına, bireylerin ve toplulukların yaşam kalitesi düzeylerinin yükselmesine, yaşam seviyelerinin yükselmesinin sürdürülebilirliğini imkân sağlayan sistem veya sistemler oluşturmaya ve bireylerin sosyal gelişmeden faydalanılmasına yönelik olarak koşullar oluşturma potansiyelidir (Stern, Wares, Orzell ve O'sullivan, 2014). Başka bir tanıma göre sosyal gelişme, ekonomik büyüme, orta sınıflaşma ve sosyal bütünleşme kapsamında kültürel ve ekonomik bütünleşme arasında birbirlerini ilgilendirecek, ilişkilendirecek ve tamamlayacak faaliyetleri sağlama kapasitesi olarak açıklanmaktadır (Öksüz, 1972: 25).

Sosyal gelişme, ülkelerin toplumların temel insani gereksinimlerini karşılama sorumluluğunun olması kapsamında söz konusu gereksinimlerin karşılanma değişimini de belirtmektedir (Estes, 1984). Buna göre, sosyal gelişmeyi bağımsız, temel insani gereksinimlerini ise bağımlı değişken olarak düşündüğümüzde, sosyal gelişmenin bir noktadan diğer bir noktaya kadarki integrali, temel insani gereksinimlerin değişimini veya sosyal değişimi belirtmektedir. Sosyal değişim aynı zamanda, sosyal gelişmeyi sağlayacak sosyal işlevlerin birbirleri üzerinde aynı sonucu sağlayacak şekilde olabilmelerinin derecesini de göstermektedir (Erkal, 1982: 25). Dolayısıyla sosyal gelişmeyi sağlayacak değişkenlerin birbirlerinin alternatifi olmadan bir bütün olarak değerlendirilmesi ve buna bağı olarak sosyal gelişme için sosyal değişkenlerin birbirlerini pozitif yönde sağlaması kapsamında sosyal değişkenlerin birbirlerini ilgilendirecek faaliyetlerde bulunulması önemlidir. Bunun yanında, sosyal değişme beşeri durumların olumlu veya olumsuz yönünü açıklamakta, buna karşın sosyal gelişme ise sadece beşeri durumların iyileşmesi sonucu oluşan katma değeri veya olumlu getiriyi belirtmektedir (Kubiczek, 2014).

Ülkeler kendilerinin ve diğer ülkelerin sosyal gelişim performanslarını takip etmektedirler. Ülkeler ilk olarak kendilerinin sosyal gelişim performanslarını analiz ederek sosyal gelişim konusundaki üstünlüklerini ve eksikliklerini belirleyebilmektedirler. Böylelikle ülkeler, mevcut sosyal politikalarını ve stratejilerini etkin, etkili ve verimli bir şekilde sonraki dönemler için uygulayabilmektedirler. Ayrıca ülkeler, diğer ülkelerin sosyal gelişim performanslarını da takip ederek sosyal gelişme konusunda geliştirilmesi gereken veya noksan hususların iyileştirilmesi için sosyal gelişme konusunda ileri seviyede veya başarılı olan ülkeler ile işbirlikleri veya ortaklıklar sağlayabilmektedirler. Bunun yanında, ülkelerin kendilerinin ve diğer ülkelerin sosyal gelişme performansları konusunda farkındalık kazanmasıyla, ülkeler mevcut ekonomik kazanımlarını kendilerinin veya diğer ülkelerin sosyal ve çevresel performanslarının gelişmesine rahatlıkla dönüştürebilip ekonomik performanslarını artırabilirler (Porter, Stern ve Green, 2014a: 11). Çünkü ülkeler, söz konusu sosyal gelişme konusundaki farkındalı̆̆ı ve hâkimiyeti ile sosyal gelişme konularında farklı stratejiler ve politikalar uygulayabilip ekonomik olarak gelecek dönemlerde hangi piyasada veya piyasalarda yoğun faaliyet göstermeleri konusunda etkinlik sağlarlar ve buna bağlı olarak ticaret ve iş faaliyetlerini daha anlamlı olarak yapabilmektedirler (Pate ve Sweo, 2016). Kişi başı gayri safi yurtiçi hasılanın (KBGSYiH) ülkelerin sosyal gelişmelerinin ölçülmesinde yetersiz kalması ve buna bağlı olarak bireylerin sosyal gelişimlerinin sağlanmasında beşeri değişkenlerin önemli etkisinin olduğunun farkına varılması, ülkelerin sosyal gelişme kapasitelerinin ölçülmesine yönelik çalışmaların oluşmasına neden olmuştur. Çünkü ekonomik büyüme son yarım yüzyılda yüz milyonlarca insanı yoksulluktan kurtarmış ve daha fazlasının yaşamını iyileştirmiş olmasına rağmen toplumsal kalkınmanın tek başına ekonomik ilerlemeye bağlı kılınması, toplumların tam olarak intiyaçlarına karşılık verememiştir. Aynı zamanda sosyal gelişme, ekonomik çerçevede üretimden ve yaşam standardından daha geniş bir kavram olup, insanların hayatında yer edinen değerlilikleri etkileyen ve maddi yönün çok ötesine geçen birçok faktörü içinde barındırmaktadır (Stiglitz, Sen ve Fitoussi, 2008; Porter, Stern ve Green, 2015a). Dolayısıyla bütün bunlara göre, ülkelerin sosyal gelişim performanslarının ölçülmesi büyük önem arz etmekte olup, ülkelerin sosyal gelişim performanslarını ölçen endekslere veya metriklere her zaman gereksinim duyulmaktadır (Porter, Stern ve Green, 2014b).

Ülkelerin sosyal gelişme performansının tespit edilmesinin önemi çerçevesinde uluslararası alanda ülkelerin sosyal gelişim performanslarının ölçülmesine yönelik çeşitli endeksler oluşturulmuştur. Bunlar; 1970 yılında Davis Morris tarafından oluşturulan "Fiziksel Yaşam Kalitesi Endeksi (The Physical Quality of Life Index - PQLI)" (Morris, 1980), 1970'li yıllarda Richard C. Estes tarafından oluşturulan "Ağırlıklı Sosyal Gelişme Endeksi (Weighted Index of Social Progress - WISP)" (Sharma, 2003), 1990 yılında Mahbul UI Hag tarafından 
oluşturulan “insani Gelişme Endeksi (Human Developmen Index - HDI) (Kaya, 2018) olarak belirtilmektedir. Buna karşın belirtilen endekslerin ekonomik ve politik özgürlükleri, geliri ve sosyal hizmetleri, güvenliği, şeffaflığı ve diğer idari ve beşeri değişkenleri detaylı olarak kapsamamalarından dolayı ekonomik yapılardan ziyade sosyal gelişmenin önceliğini oluşturan insanların temel ihtiyaçlarına ve yaşam kalitelerine birlikte yaklaşan ve odaklanan analizlerin yapılması gereksinimi oluşmuştur. Buna bağlı olarak söz konusu gereksinimin sağlanması amacıyla 2012 yılında kurulan ve "Social Progress Impeartive" isimli organizasyon tarafından "Sosyal Gelişme Endeksi (Social Progress Index - SPI)" oluşturulmuştur (Sökmen, 2014).

SPI, dolaylı ve doğrudan ülkelerin sosyal gelişim performanslarını ölçen diğer endekslere kıyasla toplumların sosyal gelişme hususlarını ve yöntemini daha ayrıntılı ve içerikli olarak açıklamaktadır (Karmowska, 2017). SPI; "temel insani gereksinimler", "refahın temelleri" ve "fırsatlar" olmak üzere toplam üç boyuttan oluşmaktadır. Temel insani gereksinimler boyutu; "beslenme ve temel tıbbi bakım", "su ve temizlik", "barınma", "kişisel güvenlik", refahın temelleri boyutu; "temel bilgiye erişim", "bilgiye ve haberleşmeye erişim", "sağlık", "çevre kalitesi" ve son olarak fırsatlar boyutu ise "bireysel haklar", "bireysel özgürlük ve seçim hakkı", "kapsayıcılık" ve "ileri eğitime erişim" bileşenlerini kapsamaktadır (Navarro, Albornoz ve Saldaña, 2019: 7). Ayrıca bileşenlerin aritmetik ortalamalarıyla boyutlar, boyutların aritmetik ortalamalarıyla SPI ölçülebilmektedir (Stern vd., 2014a).

GSYiH'nın sosyal refahın göstergesi olarak kullanılması, çeşitli eleştirilere neden olmuştur. Çünkü 2008 yılında oluşan ekonomik kriz döneminde ülkelerin sosyal gelişiminin GSYiH potansiyeli göre değerlendirilerek, sosyal gelişme konusunda gelişmiş ülkeleri olduğundan daha iyi, gelişmekte olan ülkeleri ise olduğundan daha kötü göstermiştir. Bu kapsamda GSYiH, sosyal refah göstergesi olarak gelişmiş ülkelerin sosyal konularda zayıflıklarını gizlediği, gelişmekte olan ülkelerin ise kuvvetli özelliklerini yansıtmadığı ileri sürülmüştür. GSYiH'nın temsiliyet sınırının netleşmesi ve toplumların başarısının ekonomik büyümenin üzerinde sosyal gelişme düzeyleri ile belirlenmesi gerektiği görüşleri ileri sürülmüştür (Çoşkun, Özgenç ve Güneş, 2015: 12). Dolayısıyla SPI'nın en önemli özelliklerinden bir tanesi ekonomik gelişmelerden bağımsız olarak ülkelerin sosyal gelişim performanslarının belirlenmiş olmasıdır (Stern ve Epner, 2019). SPI'nın ekonomik olmayan boyutlara odaklanması, SPI'nın doğrudan sosyal gelişmeyi ölçtüğünü göstermektedir (Porter, Stern ve Green, 2016a: 2). SPI ayrıca bir dizi metodolojik seçeneği içermektedir. Bunlar; SPI'nın ulusal performansın ekonomik olmayan boyutlarına odaklanması, girdi ölçütlerinden ziyade sonuç göstergelerine dayalı bir ölçüm yaklaşımına sahip olması ve SPI'yı oluşturan boyutların ve bileşenlerin bütünleşik bir yapı içinde olmasıdır (Stern, Wares ve Orzell, 2015: 5). Bunun yanında SPI, temel anlamda ülkelerin sosyal gelişmelerini çok farklı açılardan karşılaştırma olanağı sunmaktadır. Böylelikle ülkelerin sosyal gelişim konularındaki zayıf ve üstün yönlerinin analizi kolaylıkla sağlanabilmektedir (Stern, Wares ve Epner, 2017: 3).

SPI'yı oluşturan boyutların ve bileşenlerin birbirleri ile ilişki içinde olup, birbirlerini tamamlamaktadırlar (Stern, Wares ve Epner, 2018: 5; Social Progress Imperative, 2019: 5). Fakat SPI raporunda SPI bileşenlerinin birbirlerini tamamlama dereceleri belirtilmemiştir. Dolayısıyla SPI boyutlarının ve bileşenlerinin birbirleri arasında anlamlı, pozitif yönlü ve yüksek ilişkinin olması, ülkelerin sosyal gelişmelerini tamamladığını ya da sosyal gelişme sürecine girdiğini göstermektedir. Çünkü SPI boyutları ve bileşenleri birbirleri ile olan ilişki yapısı içinde birbirlerini sağlayarak birbirlerinin gelişimine katkı sağlayabilmektedirler. Dolayısıyla ülkelerin sosyal gelişme sürecine girmeleri veya sosyal gelişme seviyelerini yükseltmeleri için bileşenlerin veya boyutların birbirlerini ilgilendiren konularda faaliyet göstermeleri önem arz etmektedir. Buna bağlı olarak SPI bileşenleri ve boyutları arasındaki ilişkinin sürdürülebilirliği, ilgili SPI bileşeninin ve boyutunun sinerjik bir özelliğe ve uzmanlaşılan bir yapıya sahip olmasına katkı sağlayabilmektedir. Bu kapsamda ülkelerin sosyal gelişme performanslarının ölçümünün yanında, ülkelerin SPI boyutlarının ve bileşenlerinin birbirlerini tamamlama performansının ölçümü de önem kazanmaktadır (Social Progress Imperative, 2019).

Literatür incelendiğinde, Avrupa Birliği ülkelerinin SPI bileşenlerine ait veriler üzerinden bileşenler arasındaki ilişki durumunu inceleyen bir araştırmaya rastlanılmamıştır. Bu kapsamda bu araştırma, belirtilen niteliği kapsayan literatürdeki ilk araştırmadır. Ayrıca araştırmada ülkelere göre SPI bileşeninin veya bileşenlerinin ilişkisel yapıya katkı değerleri ölçülmüş ve ülkelerin sosyal gelişim performanslarını artırmaları için hangi bileşenin ilişkisel yapıya katkısının olması gerektiği ortaya çıkarılmıştır. Bunun yanında, araştırma 
çerçevesinde hesaplanan nicel değerler, araştırmacılar için veri seti niteliği taşımaktadır. Ülkelerin SPI boyutlarının ve bileşenlerinin birbirini tamamlama kapasitesinin önemi kapsamında araştırmanın ikinci bölümünde sosyal geliş̧me, SPI ve Somer D ilişki katsayısı ve DEMATEL yöntemi ile ilgili araştırmalar sunulmuştur. Üçüncü bölümde araştırmanın yöntemi ve dördüncü bölümde Avrupa Birliği ülkelerine göre SPI boyutları ve bileşenleri arasındaki ilişki yapısı Somer d temelli DEMATEL yöntemi ile tespit edilmiştir. Son bölümde ise araştırmada tespit edilen bulgulara göre çıkarımlar, değerlendirmeler ve öneriler oluşturulmuştur.

\section{Literatür}

Literatür iki açıdan değerlendirilmiştir. Bunlardan birincisi, SPI ile ilgili araştırmalardır. íkincisi ise araştırmada kullanılan yöntem açısından Somer D ve DEMATEL yöntemi ile ilgili olan çalışmalardır.

Porter vd. (2014a) 2014 yılı için ülkelerin SPI değerlerini tespit etmişlerdir. Araştırmada, SPI değerleri en fazla olan ilk üç ülkenin Yeni Zelanda, İsviçre ve İzlanda olduğu tespit edilmiştir. Araştırma kapsamında ayrıca SPI değerleri en yüksek olan ilk 10 ülke arasında Hollanda, Norveç, İsveç, Finlandiya ve Danimarka ülkelerinin Kuzey Avrupa ülkeleri olması kapsamında dikkat çekici olduğu ifade edilmiştir. Araştırmacılar ayrıca Kosta Rika ülkesinin KBGSYiH değerinin yüksek olmamasına rağmen SPI sıralamasında 25'inci ve Birleşik Arap Emirlikleri ülkesinin KBGSYiH açısından çok yüksek performansa sahip olmasına rağmen SPI sıralamasında 37'inci olduğunu tespit etmişlerdir. Dolayısıyla araştırmacılar, KBGSYiH'nın sosyal gelişmeyi pozitif yönlü olarak sağlayabileceğini, fakat KBGSYiH ülkelerin sosyal gelişimini sağlamasında garantör bir etken olmadığını belirtmişlerdir. Araştırma kapsamında ayrıca Avrupa, Kuzey Amerika, Okyanusya kıtalarının genel olarak sosyal gelişme açısından iyi olduğu, buna karşın Sahra Altı Afrika, Orta ve Güney Asya bölgelerinin sosyal gelişme açısından iyi performans sergileyemedikleri sonucuna ulaşılmıştır. Porter, Stern ve Green (2015b), 2015 yılı için 133 ülkenin sosyal gelişme performanslarını SPI bileşenleri kapsamında ölçmüşlerdir. Araştırmada, ülkelerin SPI değerleri ortalamasının 61 olduğunu ve bazı ülkelerin SPI değerlerinin, dünya SPI ortalaması değeri ile arasında belirgin farklılıklar olduğu bulgusuna ulaşmışlardır. Araştırmacılar bunun yanında, ortalama dünya SPI değerinden yüksek olan dünya ortalama SPI bileşenlerinin beslenme ve temel tıbbi bakım $(87,47)$, su ve temizlik $(68,57)$, temel bilgiye erişim $(85,98)$, bilgiye ve haberleşmeye erişim $(63,56)$, sağlık $(64,67)$ ile bireysel özgürlük ve seçim hakkı $(61,23)$ olduğunu ifade etmişlerdir. Bunların dışında araştırmada, ekonomik ilerleme ile sosyal ilerleme arasında anlamlı ilişki olmasına rağmen ekonomik performansın tek başına sosyal gelişmeyi sağlayamadığını belirtmişlerdir. Porter, Stern ve Green (2016b), 133 ülkenin sosyal gelişim performanslarını SPI kapsamında ölçmüşlerdir. Bulgulara göre, SPI dünya ortalamasının 62,88 olduğu tespit edilmiştir. Araştırmada, çevresel kalite $(59,02)$, ileri eğitime erişim $(50,63)$, kapsayıcılık $(40,39)$ bileşenleri hariç SPI'yı oluşturan diğer 9 bileşeninin dünya ortalamalarının, SPI dünya ortalamasından yüksek olduğunu gözlemlemişlerdir. Araştırmacılar, demografik tespitlerine göre, çok yüksek SPI değerine sahip ülkelerin hemen hemen eşit sayıda yaş gruplarına (25 yaş üstü, 25-55 ve 55 üstü) sahip olduklarını ve 25 yaş altı genç nüfusu fazla olan ülkelerin genel anlamda sosyal gelişim performanslarının düşük olduğunu tespit etmişlerdir. Araştırmada ayrıca 25 yaş üstü nüfusu fazla olan ülkelerin ise sosyal gelişim performanslarının genel anlamda yüksek seviyede olduğu bulgusuna ulaşılmıştır. Jahic ve Cinjanevic (2017), ülkelerin 2013 yılındaki Birleşmiş Milletler Eğitim Endeksi değerleri ile 2016 yılına ait SPI ve Yolsuzluk Algı Endeksi (Corruption Perception Index) değerleri üzerinden sosyal gelişmenin ve eğitimin yolsuzluk değerleri ile olan ilişkilerini araştırmışlardır. Araştırmada, sosyal gelişmenin ve eğitimin yolsuzluk değişkenine anlamlı ve pozitif yönde etkisinin olduğu bulgusuna ulaşılmıştır. Porter, Stern ve Green (2017), 128 ülkenin SPI bileşenleri ile sosyal gelişim performanslarını ölçmüşlerdir. Araştırmacılar ülkelerin SPI değerlerine göre çok yüksek seviye, yüksek seviye, orta üst seviye, orta alt seviye, düşük seviye ve çok düşük seviye olarak gruplandırmışlardır. Bulgulara göre, çok yüksek sosyal gelişme performansına sahip olan ilk üç ülkenin Danimarka, Finlandiya ve İzlanda, yüksek sosyal gelişim performansı sağlayan ilk üç ülkenin Belçika, İspanya ve Japonya, orta üst sosyal gelişme performansı sağlayan ilk üç ülkenin Mauritius, Panama ve Bulgaristan, orta alt sosyal gelişme performansı sağlayan ilk üçülkenin El Salvador, Libya ve Moldova, düşük sosyal gelişme performansı sağlayan ilk üç ülkenin Kenya, Myanmar ve Bangladeş ve çok düşük sosyal gelişme performansı sağlayan ilk üç ülkenin ise Yemen, Nijer ve Gine olarak tespit edilmiştir. Araştırmada ayrıca ülkelerin SPI ile KBGSYiH değerleri arasında pozitif yönlü, anlamlı ve yüksek seviyede ilişki olduğu ve ilişkinin doğrusal 
olmadığı tespit edilmiştir. Buna göre, düşük gelire sahip ülkelerde KBGSYiH'da meydana gelen küçük değişmenin sosyal ilerlemeyi çok fazla sağladığı, fakat yüksek KBGSYiH'ya sahip ülkelerde ise KBGSYiH'larındaki küçük değişimin ülkelerin sosyal gelişmelerini KBGSYiH'sı düşük olan ülkelere kıyasla artırmadığını tespit etmişlerdir. Romero, Montero ve Ruales (2017), 2006-2014 yılları arasındaki Ekvator ülkesinin SPI ve GSYiH değerleri arasındaki ilişkiyi belirlemişlerdir. Araştırmada, Ekvator ülkesinin belirtilen yıllara göre SPI le GSYiH değerleri arasında anlamlı, pozitif yönde ve yüksek seviyede ilişki olduğu ölçülmüştür. Social Progress Imperative Organizasyonu (2018) 2018 yılı için 146 ülkenin SPI değerlerini ölçmüştür. Araştırmada, çok yüksek sosyal gelişim performansını sağlayan ilk üç ülkenin Norveç, İzlanda ve İsviçre, yüksek sosyal gelişim performansı sağlayan ilk üç ülkenin Avustralya, Fransa ve Belçika, orta üst sosyal gelişme performansı sağlayan ilk üç ülkenin Bulgaristan, Barbados ve Arjantin, orta alt sosyal gelişme performansı sağlayan ilk üç ülkenin Güney Afrika, Kırgızistan ve Bhutan, düşük sosyal gelişme performansı sağlayan ilk üç ülkenin Myanmar, Bangladeş ve Ruanda, çok düşük sosyal gelişme performansı sağlayan ilk üç ülkenin ise Angola, Gine ve Sudan olduğunu ifade etmişlerdir. Araştırmada ayrıca dünya ortalama SPI'ının 63,46 olduğunu ve SPI'yı oluşturan bileşenlerden güvenlik $(55,68)$, sağılık $(56,49)$, kişisel haklar $(61,34)$, bireysel özgürlük ve seçim hakkı $(40,17)$, ileri eğitime erişim $(39,36)$ bileşenlerinin dünya ortalama SPI'yı geçemediğini belirlemişlerdir. Özgür Güler, Güler ve Şanlı (2019), 2016 yılı için 138 ülkenin SPI bileşenlerinden olan temel insani ihtiyaçlar boyutu kapsamında beslenme ve temel tıbbi bakım, su ve temizlik, barınma, güvenlik bileşenleri ile fırsatlar boyutu kapsamında kişisel haklar, bireysel özgürlük ve seçim hakkı, katılımcılık ile ileri eğitime erişim bileşenleri arasındaki ilişkiyi kanonik korelasyon yöntemi ile ölçmüşlerdir. Araştırmada, beslenme ve temel tıbbi bakım ile fırsatlar boyutu arasındaki ilişkinin anlamlı, pozitif yönlü ve yüksek seviyede olduğu tespit edilmiştir. Söz konusu boyutlar arasında ilişkiye en fazla katkı sağlayan bileşenlerin sırasıyla ileri eğitime erişim ve barınma olduğu tespit edilmiştir. Araştırma kapsamında ayrıca temel insani gereksinimler ile fırsatlar boyutu arasındaki ilişkiye temel insani gereksinimler boyutu, fırsatlar boyutuna kıyasla ilişkisel yapıya daha çok katkı sağladığı belirlenmiştir. Social Progress Imperative Organizasyonu (2019) 2019 yılı için 149 ülkenin SPI değerlerini hesaplamışlardır. Sonuçlara göre, sosyal gelişim performansı en yüksek olan ilk üç ülkenin Norveç, Danimarka ve İsviçre, sosyal gelişim performansı yüksek olan ilk üç ülkenin Lüksemburg, İspanya ve Portekiz, sosyal gelişim performansı orta üst olan ilk üç ülkenin İsrail, Litvanya ve Polonya, sosyal gelişim performansı orta alt olan ilk üç ülkenin Senegal, Nikaragua ve Hindistan, sosyal gelişim performansı düşük olan ilk üç ülkenin Moritanya, Angola ve Madagastar ve son olarak sosyal gelişim performansı en düşük olan ilk üç ülkenin ise Güney Sudan, Orta Afrika Cumhuriyeti ve Çad olduğu belirlenmiştir. Araştırma kapsamında dünya SPI ortalamasının 64,47 olduğu, bu ortalama niceliğinden düşük seviyede olan dünya ortalaması bileşen değerlerinin güvenlik $(61,82)$, sağlık $(59,89)$, çevresel kalite $(58,86)$, bireysel haklar $(61,44)$, bireysel haklar ve özgürlükler $(60,55)$, kapsayıcılık $(41,51)$ ve ileri eğitime erişim $(42,59)$ olduğu tespit edilmiştir. Social Progress Imperative Organizasyonu (2020) 2020 yılı için 163 ülkenin SPI değerlerini hesaplamışlardır. Bulgulara göre, çok yüksek sosyal gelişim performansı sağlayan ilk üç ülkenin Norveç, Danimarka ve Finlandiya, yüksek sosyal gelişim performansı sağlayan ilk üç ülkenin Lüksemburg, Avusturya ve Belçika, orta üst sosyal gelişim performansı sağlayan ilk üç ülkenin Hırvatistan, Macaristan ve Arjantin, orta alt sosyal gelişim performansı sağlayan ilk üçülkenin Libya, Botsvana ve Bolivya, düşük seviyede sosyal gelişim performansı sağlayan ilk üç ülkenin Honduras, Guatemala ve Timor ve en düşük seviyede sosyal gelişim performansı sağlayan ilk üç ülkenin ise Ekvator Ginesi, Kore Demokratik Cumhuriyeti ve Burkina Faso olduğu tespit edilmiştir. Araştırmada SPI dünya ortalamasının 64,24 olduğunu, bu ortalamanın aşağısında kalan bileşen ortalamalarının güvenlik $(62,15)$, sağlık $(60,88)$, çevresel kalite $(36,87)$, kişisel haklar $(60,09)$ ve bireysel özgürlük ve seçim hakkı $(63,29)$ ile kapsayıcılık $(39,25)$ olduğu belirlenmiştir. Bunların dışında, ülkelerin KBGSYiH ile SPI değerleri arasında anlamlı, pozitif ve yüksek seviyede ilişki olduğu tespit edilmiştir. Buna karşın, Katar, Bahreyn ve Suudi Arabistan ülkelerinin KBGSYiH değerlerinin yüksek olmasına rağmen sosyal gelişim performanslarının yüksek olmadığı değerlendirilmiştir.

Winters, Stinchfield ve Fukerson (1993), yaşları 15 ile 18 arasında değişen 702 genç üzerinden sağladığı veriler ile söz konusu gençlerin kumar oynama durumlarını nedensel analiz çerçevesine değerlendirmişlerdir. Araştırma sonucuna göre, para miktarının ve kumara başlama süresinin durumun ciddiyeti ile Somer D ilişki katsayısına göre anlamlı ve pozitif yönde ilişkinin olduğu tespit edilmiştir. Dolayısıyla araştırma kapsamında, gençler kumar oynamaya alıştıkça ve kumar için para miktarını artırdıkça, gençlerde 
kumar oynamanın yanlış davranış olduğu algısının belirginleştiği sonucuna ulaşımıştır. Newson (2002), Kendall's Tau-a, Somer D ve Hodges-Lehmann ilişki katsayılarının güven limitleri ile güven limitlerinin farklıık değerlerinin Wilcoson testinde, ROC eğri analizinde, Harrell $C$ ve Theil medyan eğimi kapsamında parametrelerin tespit edilmesinde önemli ve etkili olduklarını ifade etmiştir. Tzeng, Chiang ve Li (2007), eöğrenmenin etkin, etkili ve verimli olmasına yönelik bir model önermişlerdir. Araştırmacılar modelde eöğrenmeyi sebep ve sonuç ilişkisi içinde değerlendirerek bağımsız değişkenlerin karakterlerini faktör analizi, bağımlı değişkenlerin karakterini ise DEMATEL yöntemi ile belirlemişlerdir. Araştırmada, e-öğrenmeyi sağlayan kriter sayısının fazla ve kriterlerin önemlilik değerlerinin birbirine yakın değerde olduğundan, önerilen model ile e-öğrenmenin sağlanabileceğini ifade etmişlerdir. Karagöz (2010a), Cumhuriyet Üniversitesi İktisat Fakültesi'nde öğrenim gören 800 öğrenci üzerinden sağlanan verilere göre ailenin aylık ortalama gelirinin, öğretim üyesinin konusuna hâkim olmasının, öğretim üyesinin eleştiriye açık olmasının, öğretim üyesinin öğrenci ile olumlu etkileşiminin, öğrencinin ders ile ilgili bilgilerini gelecekte kullanabileceğine inanmasının ve öğrencinin ders içeriğini sevmesinin öğrencinin başarısı arasında ilişkileri Somer D ilişki katsayısı ile belirlemiştir. Araştırmada, ailenin ortalama gelirinin, öğretim üyesinin konusuna hâkim olmasının ve öğretim üyesinin eleştiriye açık olmasının öğrencinin başarısı ile olan ilişkilerin anlamlı olduğu, diğer değişkenlerin ise başarı ile anlamlı ilişkilerin olmadığı tespit edilmiştir. Özen Kutanis, Öncü, Mesci ve Çömlekçi (2013), Erzurum ilinde faaliyet gösteren 78 bankanın 30 şubesinde çalışan toplam 450 banka görevlisi üzerinden sağladığı verilere göre 2008 ve 2009 yılları arasındaki küresel ekonomik krizin bankacılık sektöründeki iş görenlerin iş tatminine ve örgütün performansına olan etkilerini Somer $D$ ilişki katsayısı ile ölçmüşlerdir. Araştırmada iş görenlerin iş tatminine ve örgütün performansına anlamlı ve pozitif yönde etkisinin olduğu sonucuna ulaşılmıştır. Shien, Wu ve Huang (2010), Tayvan ülkesinde Changhua şehrindeki Shaw Chwan Memorial hastanesinde hastane performansını etkileyen yedi ana kriteri SERVQUAL anketi ile hasta ve hasta yakınları üzerinden belirlemişlerdir. Devamında araştırmacılar, DEMATEL yöntemi ile hastane performansını belirleyen kriterlerin ilişkisel yapısına en fazla katkı sağlayan kriteri, kriterlerin ilişki niteliğini ve ilişkisel yapıdaki en önemli kriterin önemlilik derecesini tespit etmişlerdir. Araştırmada, mesleki yeterliliğe sahip güvenilir sağlık personelin kriterler arasındaki ilişkisel yapıya en fazla katkı sağlayan ve ilişkisel yapıda en önemli kriter olduğu gözlenmiştir. Ayrıca araştırma kapsamında, ilişkisel yapıda yeterli donanımlılık, iyi iletişime sahip sağlık personeli, mesleki yeterliliğe sahip güvenilir sağlık personeli, sağlık personelinin problem çözme becerisi kriterlerinin "etkileyen", hastaların durumu ile ilgili kapsamlı bilgi sunumu, profosyonel yeteneklere sahip sağlık personeli ve eczacıların tavsiye nitelikleri kriterlerin "etkilenen" niteliğine sahip olduğu gözlenmiştir. Chang, Chang ve Wu (2011), tedarik zinciri yönetimi konusunu oluşturan kriterlerin arasındaki ilişkisel yapıyı DEMATEL yöntemi kapsamında belirlemişlerdir. Bulgulara göre, söz konusu ilişkisel yapı çerçevesinde ilişkisel yapıya en fazla katkı sağlayan, ilişkisel yoğunluğu ve önemlilik derecesi en fazla olan kriterin malların istikrarlı teslimatının olduğu tespit edilmiştir. Jassbi, Mohamadnejad ve Nasrollahzade (2011), organizasyonlarda Balanced Scorecard sisteminin oluşturulmasında en önemli işlevin strateji haritalama olduğunu vurgulamışlardır. Araştırmacılar, strateji haritalamanın oluşturulmasında bir organizasyondaki tüm olası stratejik hedefler arasında neden-sonuç ilişkisinin kurulmasının önemli olduğunu ifade etmişlerdir. Buna istinaden araştırmacılar, stratejik hedefler arasında neden ve sonuç ilişkisinin DEMATEL yöntemi ile sağlanabileceğini ve strateji haritasının oluşturulmasında belirsizlik durumları bulanık DEMATEL yöntemi ile aşılabileceğini belirtmişlerdir. Çınar (2013), Haziran-Ekim 2012 ayları arasında üniversite öğrencilerine ait ilgili değerler üzerinden öğrencilerin meslek tercihlerinde etkili olan kriterler arasında ilişkisel yapıda kriterlerin ilişkisel yapıya katkı, etkileme, etkilenme, ilişkisel yoğunluk ve önemlilik derecelerini ölçmüşlerdir. Araştırmada, kriterlerin ilişkisel yapıya katkı değerleri finans, kendini geliştirme, sağık, sosyallik ve etik yapı, etkilenme değerleri sosyallik, etik yapı, kendini geliştirme, finans ve sağlık, ilişkisel yoğunluk değerleri ise finans, sosyallik, kendini geliştirme, sağlık ve etik yapı olarak sıralanmıştır. Araştırma kapsamında kriterler arasındaki ilişkisel yapıda finans, sağlık ve kendini geliştirme "etkileyen", sosyallik ve etik yapı ise "etkilenen" niteliğine sahip olduğu gözlenmiştir. Son olarak söz konusu ilişkisel yapıda kriterlerin önemlilik derecesi ise sırasıyla finans, sağlık, kendini geliştirme, sosyallik ve etik yapı olarak belirlenmiştir. Karaatlı, Ömürbek, Işık ve Yılmaz (2016), Türkiye Şeker Fabrikaları Anonim Şirketine bağlı olan 23 şeker fabrikasının 2008-2012 yılları arasındaki verileri ile fabrikaların performansını etkileyen kriterlerin önemlilik değerlerini DEMATEL, şeker fabrikaların performanslarını ise DEMATEL temelli TOPSIS yöntemi ile 
ölçmüşlerdir. Araştırma bulgularına göre, DEMATEL yöntemi ile şeker fabrikalarının performanslarını etkileyen kriterlerin önemlilik dereceleri şeker üretimi, fiilen işlenen pancar, satış miktarı, makine kapasitesi, melas miktarı, yakıt tüketimi ve iş gücü olarak sıralanmıştır. DEMATEL temelli TOPSIS yöntemine göre en iyi performans sağlayan fabrikanın Ereğli Şeker Fabrikası olduğu sonucuna ulaşılmıştır. Paksoy (2017a), bilgi sistemlerinde kritik başarı faktörlerinin ve faktörleri oluşturan bileşenlerin kendi aralarındaki ilişkileri DEMATEL yöntemi ile tespit etmiştir. İlk olarak araştırmada, kritik başarı faktörleri arasındaki ilişkide proje ve katılım başarı faktörleri etkileyen, yönetim, sunum ve bakım başarı faktörleri ise etkilenen nitelikte olduğu bulgusuna ulaşılmıştır. İkinci olarak ise ilişkisel yapıya en fazla katkı sağlayan kritik başarı faktör değişkenlerinin uygulamayı test etmek için son kullanıcı katkıları, zamanında ve dengeli bütçe sunumu (C32), mantıksız işlemlerle birlikte standart işlemlere sahip test modülleri, uygulanan projenin belirli bir zamana paralel olarak eski sistemle çalıştırma (C33) ve projenin zamanında olması üzerinde müşterinin etkisi (C17) olarak sıralandığı tespit edilmiştir. Üçüncü olarak ise ilişkisel yoğunluğu en fazla olan kritik başarı faktörleri değişkenleri görev için eylemleri kontrol etme ve izleme, uygun çalışma gruplarının oluşturulması, C32, C33 ve C17 olarak sıralandığı gözlenmiştir. Albayrak ve Erkayman (2018) sporcuların akıllı bileklik tercih sürecini kolaylaştırmak için çok kriterli karar verme (ÇKKV) yöntemlerinden bulanık DEMATEL yöntemi kullanarak söz konusu akıllı bileklerin tercih süresini kolaylaştıran kriterlerin önemlilik derecelerini tespit etmişlerdir. Sonuçlara göre, akıllı bileklik seçiminde en önemli kriterin akıllı bileklerin kullanım kolaylığı olduğu belirlenmiştir. Diğer kriterlerin önemlilik dereceleri estetik, fonksiyonel özellik, ağırlık ve batarya kullanım süresi olarak sıralanmıştır. Abdel-Basset, Manogaran, Gamal ve Smarandache (2018), tedarik seçiminin organizasyonların üretkenliğini ve kârlılı̆ını oluşturmada önemli bir faktör olduğunu vurgulamışlardır. Bu kapsamda araştırmacılar, merkezi İngiltere'de bulunan Flopater ve merkezi Birleşik Arap Emirlikleri'nde bulunan Cosmoplast isimli firmaların ilgili verilerine göre tedarik seçiminin belirleyen kriterlerin birbirlerini tamamlamasında ilişkisel yapıya en fazla katkı sağlayan kriteri ve kriterlerin ilişki niteliğini DEMATEL yöntemi ile tespit etmişlerdir. Araştırma sonucuna göre, söz konusu firmalara göre ilişkisel yapıya en fazla katkı sağlayan tedarik seçimi kriterinin maliyet olduğunu belirlemişlerdir. Ayrıca araştırmada, ilişkisel yapıda zamanında teslim, kalite, müşterilere karşı sorumluluk kriterlerinin "etkileyen", buna karşın inovasyon, ve itibar kriterlerinin "etkilenen" niteliğe sahip olduğu tespit edilmiştir. Battal (2018), Türkiye'de ki havayolu firmaların finansal problemler arasındaki ilişki yapısını DEMATEL yöntemi ile tespit etmişlerdir. Araştırmada, havayolu firmaların finansal problemleri arasındaki ilişkisel yapıya en fazla katkı sağlayan, ilişkisel yapıda önemlilik derecesi en fazla olan kriterin finansal yönetim ve yapılanma sorunları, ilişkisel yapıda etkilenme değeri en fazla olan kriterin ise finansman kaynaklarının kullanımındaki yasal sorunlar olduğu tespit edilmiştir. Bunların dışında, ilişkisel yapıda finansal yönetim ve yapılanma sorunları, finansman kaynaklarının kullanımında yasal sorunlar, finansmana yönelik devlet desteklerinin olmaması ve havayolu işletmelerinde özkaynak yetersizliği ilişkisel yapıda "etkileyen", plansız yatırımlar sonucu finansman kaynaklarının israfı, finansman sorunlarında yanlış önlemler alınması, havayolları arasında işbirliğinin olmaması ve yıkıcı rekabet ve son olarak finansmanda dışa bağımlılık kriterleri ise ilişkisel yapıda "etkilenen" niteliğe sahip olduğu bulgusuna ulaşılmıştır. Altıntaş (2020), 2018 ve 2019 yılları için ülkelerin Küresel Rekabet Endeks ve Küresel İnovasyon Endeks değerleri üzerinden inovasyon ve rekabet boyutları arasındaki homojen ilişkiyi ilişki katsayıları, inovasyon ve rekabet boyutları arasındaki homojen-heterojen ilişkiyi ise DEMATEL yöntemi ile belirlemiştir. Araştırmada, DEMATEL yöntemi kapsamında doğrudan ilişki katsayısı matrisi Somer D ilişki katsayısı ile sağlanmıştır. Ayrıca araştırmada, inovasyon ve rekabet boyutları arasındaki ilişkiye heterojen ilişki kapsamında inovasyon, homojen-heterojen ilişki kapsamında ise rekabet boyutu daha fazla katkı sağladığı bulgusuna ulaşılmıştır.

Literatür değerlendirildiğinde, sosyal gelişim ve SPI ile ilgili çalışmaların daha çok ülkelerin birbirlerini sosyal gelişim performanslarının birbirlerini kıyaslamasına yönelik olduğu tespit edilmiştir. Dolayısıyla literatürdeki çalışmalar, ülkelerin kendilerinin ve birbirlerinin sosyal gelişim performansları hakkında farkındalık kazandırmasına katkı sağladığı düşünülmüştür. Yine literatür incelendiğinde, ülkelerin SPI bileşenlerinin birbirleri ile olan ilişkileri açıklayan Özgür Güler vd. (2019)'nin çalışması haricinde herhangi bir araştırmaya rastlanılmamıştır. Dolayısıyla ülkelerin SPI bileşenlerini tamamlama kapasitelerinin önemi kapsamında, SPI bileşenleri arasındaki ilişkisel yapıda bileşenlerin ilişkisel yapıya katkı, etkilenme, ilişkisel yoğunluk değerlerinin ve ilişki niteliklerinin belirlemesi için nicel verilere göre daha çok Somer $D$ veya diğer 
etki katsayıları temelli DEMATEL yöntemi ile ilgili araştırmaların yapılması gerektiği sonucuna ulaşılmıştır. Çünkü ülkelerin sosyal gelişme performanslarını ayrıntılı ve kapsamlı açıklayan SPI'nın bileşenleri arasındaki ilişki yapısının DEMATEL yöntemi ile belirlenmesiyle SPI'nın daha anlamlı, detaylı, içerikli ve araştırmacılar için daha faydalı olacağı değerlendirilmiştir. Dolayısıyla bu araştırma, SPI bileşenlerinin birbirlerini tamamlamasının önemi kapsamında literatüre katkı sağladığı düşünülmüştür.

\section{Yöntem}

\subsection{Araştırmanın Amacı, Verilerin Analizi ve Veri Seti}

Araştırmanın amacı, Avrupa Birliği'ne üye 27 ülkenin 2020 için SPI'yı oluşturan verilere göre SPI boyutları arasındaki ilişkisel yapıyı belirlemektir. Söz konusu ülkelerin SPI bileşenlerinin birbirlerini pozitif yönde tamamlayacak faaliyetler yapmasıyla kendilerinin sosyal gelişim performanslarını artabilmektedir. Avrupa Birliği ülkelerinin genel anlamda refah, insani gelişmişlik, yaşam standardı ve sosyal gelişme seviyeleri yüksek düzeydedir. Buna bağlı olarak Avrupa Birliği ülkelerin sosyal politika ve stratejileri diğer ülkelerin sosyal gelişme yöntemlerini ve faaliyetlerini etkileyebilmektedir. Dolayısıyla Avrupa Birliği ülkelerin sosyal gelişim bileşenlerinin birbirini tamamlama potansiyelinin tespit edilmesinin önem arz ettiği değerlendirilmiştir.

SPI en son ve güncel olarak 2020 yılı için rapor kapsamında hazırlanmıştır. Buna bağlı olarak araştırmanın veri setini 2020 SPI raporunda belirtilen Avrupa Birliği ülkelerinin SPI bileşen değerleri oluşturmaktadır. Araştırmada sağlanan veriler açık kaynaktan alındığı için araştırma için ilgili etik kurumundan izin alınmasının gerekli olmadığı düşünülmüştür. Bu kapsamda araştırmada kullanılan veri seti ile araştırmada kolaylık göstermesi bakımından çalışmada kullanılan SPI boyut ve bileşenlerine ait kısaltmalar Tablo 1'de belirtilmiştir.

Tablo 1. SPI Boyut ve Bileşenleri

\begin{tabular}{|c|c|c|c|}
\hline Boyutlar & $\begin{array}{l}\text { Boyutların } \\
\text { Kısaltması }\end{array}$ & Bileşenler & $\begin{array}{c}\text { Bileşenlerin } \\
\text { Kısaltması }\end{array}$ \\
\hline \multirow{4}{*}{$\begin{array}{c}\text { Temel Insan } \\
\text { Gereksinimleri }\end{array}$} & \multirow{4}{*}{ Tig } & Beslenme ve Temel Tıbbi Bakım & BTTB \\
\hline & & Su ve Temizlik & ST \\
\hline & & Barınma & BAR \\
\hline & & Kişisel Güvenlik & KG \\
\hline \multirow{4}{*}{ Refahın Temelleri } & \multirow{4}{*}{ RT } & Temel Bilgiye Erişim & TBE \\
\hline & & Bilgiye ve Haberleşmeye Erişim & BHE \\
\hline & & Sağlık & SAĞ \\
\hline & & Çevre Kalitesi & ÇK \\
\hline \multirow{4}{*}{ Firsatlar } & \multirow{4}{*}{ FR } & Bireysel Haklar & $\mathrm{BH}$ \\
\hline & & Bireysel Özgürlük ve Seçim Hakkı & BÖSH \\
\hline & & Kapsayıcılık & KAP \\
\hline & & İleri Eğitime Erişim & IEE \\
\hline
\end{tabular}

\subsection{Somer D ilişki Katsayısı}

Somer D katsayısı simetrik olmayan bir özelliğe sahiptir. Dolayısıyla sıralı ölçekte iki değişken arasında bağımlı ve bağımsız ilişki durum oluştuğunda değişkenler arasındaki ilişki Somer D ilişki katsayısı ile ölçülebilmektedir. Dolayısıyla Somer $D$ ile bağımsız değişken bağımlı değişkeni ne kadar etkilediği hesaplanabilmektedir. Ayrıca değişkenler birbirlerini etkiliyorsa değişkenlerin hem bağımlı hem de bağımsız değişken olarak birbirlerini etkileme değerleri de ölçülebilmektedir. Somer D ilişki katsayısı -1 ile +1 arasında değer almaktadır. Katsayısının sıfır değerinde olması $2 \times 2$ tablolar haricinde değişkenlerin bağımsız olduğu anlamına gelmemektedir (Karagöz, 2010a; Karagöz, 2010b; Demir, 2020: 319). Ayrıca oran ölçeği, nominal, sıralama ve aralıklı ölçek türlerini kapsamaktadır (Demir, 2020: 32). Dolayısıyla oran ölçeğiyle yapılan bir 
ölçekte değişkenler arasındaki ilişki nominal, sıralı ve aralıklı ölçek türlerini için oluşturulan ilişki katsayıları kullanılabilmektedir. Buna bağlı olarak oran ölçekli bir yapıda değişkenler arasındaki ilişki katsayısı Somer D ile ölçülebilmektedir. İki değişken arasındaki ilişki bağımlı ve bağımsız değişkenler olarak tasnif edildiğinde, Somer D ilişki katsayısını tespit etmek için 11 adet uygulama adımı bulunmaktadır. Söz konusu Somer D ilişki katsayısının uygulama adımları aşağıda açıklanmıştır (Oktay, 2017: 72-93).

1. Adım: Karar Matrisinin Oluşturulması

$$
\mathrm{n}=\left[\begin{array}{ccc}
\mathrm{n}_{11} & \mathrm{n}_{12} & \mathrm{n}_{1 \mathrm{j}} \\
\mathrm{n}_{21} & \mathrm{n}_{22} & \mathrm{n}_{2 \mathrm{j}} \\
\vdots & \vdots & \vdots \\
\mathrm{n}_{\mathrm{i} 1} & \mathrm{n}_{\mathrm{i} 2} & \mathrm{n}_{\mathrm{ij}}
\end{array}\right]
$$

n matristeki her bir etki değerini göstermektedir. i satır ve j sütun değerlerini belirtmektedir.

2. Adım: $C^{*}$ Değerlerinin Belirlenmesi

$\mathrm{C}_{\mathrm{ij}}{ }^{*}$ değerleri, karar matrisinin en kuzey batısından başlanarak $(i, j)$ hücresinin güneydoğusundaki hücrelerin toplamını temsil etmektedir. Buna göre, $C_{i j}{ }^{*}$ hesaplama formülü aşağıdadır.

$$
C_{i j}^{*}=\sum_{i^{\prime}>i}^{1} \sum_{j^{\prime}>j}^{J} n_{i^{\prime} j^{\prime}}
$$

3. Adım: C Değerinin Belirlenmesi (Uyumlu çiftler)

$$
C=\sum_{i=1}^{\prime} \sum_{j=1}^{J} n_{i j} c_{i j}^{*}
$$

I, i’nin, J ise j'nin en son değerini göstermektedir.

\section{Adım: $D^{*}$ Değerlerinin Belirlenmesi}

$D_{i j}{ }^{*}$ değeri, karar matrisinin en kuzey doğusundan başlanarak $(i, j)$ hücresinin güneybatısındaki hücrelerin toplamını temsil etmektedir. Buna göre, $D_{i j}{ }^{*}$ hesaplama formülü aşağıdadır.

$$
D_{i j}^{*}=\sum_{i<i}^{1} \sum_{j^{\prime}>j}^{J} n_{i j}
$$

5. Adım: D Değerinin Belirlenmesi (Uyumsuz Çiftler)

$$
D=\sum_{i=1}^{I} \sum_{j=1}^{J} n_{i j} D_{i j}^{*}
$$

6. Adım: Sadece X Değişkenine göre bağlı olan değer sayısı $\left(T_{X}\right)$

Değişik tip bağlı değerler kapsamında $(i, j)$ hücresindeki müşahade, sadece $X$ değişkeninin $i$ 'inci satırındaki değerler ile bağlı olduğunda X'e göre bağlı olan müşahade sayısı eşitlik $\sigma^{\prime}$ da belirtilmiştir.

$$
2 T_{x}=\sum_{i=1}^{1} n_{i+}^{2}+\sum_{i=1}^{1} \sum_{j=1}^{J} n_{i j}^{2}
$$


7. Adım: Sadece Y Değişkenine göre bağlı olan değer sayısı ( $\left.T_{Y}\right)$

Değişik tip bağlı değerler kapsamında $(i, j)$ hücresindeki müşahade, sadece $Y$ değişkeninin i'inci satırındaki değerler ile bağlı olduğunda Y'ye göre bağıı olan müşahade sayısı eşitlik 7'de belirtilmiştir.

$$
2 T_{Y}=\sum_{i=1}^{1} n_{+j}^{2}+\sum_{i=1}^{1} \sum_{j=1}^{J} n_{i j}^{2}
$$

\section{Adım: $X$ ve $Y$ değişkenlerine göre bağlı olan değer sayısı $\left(T_{X Y}\right)$}

Değişik tip bağlı değerler kapsamında (i,j) hücresindeki müşahade, $X$ ve $Y$ değişkeninin i'inci satırındaki değerler ile bağıı olduğunda X'e ve Y'ye göre bağlı olan müşahade sayısı eşitlik 8'de belirtilmiştir.

$$
2 T_{X Y}=\sum_{i=1}^{1} \sum_{j=1}^{J} n_{i j}^{2}-n
$$

\section{Adım: $Y^{\prime}$ nin $X^{\prime}$ e olan etkisinin belirlenmesi $\left(\widehat{d}_{Y X}\right)$}

Multinominal örnekleme modeline bağlı olarak $\left(\widehat{\mathrm{d}}_{\mathrm{YX}}\right)$ katsayısının yüksek olabilirlik tahmincisi eşitlik 9'da belirtilmiştir.

$$
\widehat{d}_{Y X}=\frac{C-D}{C+D+T_{Y}}=\frac{2(C-D)}{n^{2}-\sum_{i=1}^{l} n_{i+}^{2}}
$$

10. Adım: $X^{\prime}$ in Y'ye olan etkisinin belirlenmesi $\left(\widehat{d}_{X Y}\right)$

Multinominal örnekleme modeline bağlı olarak $\left(\widehat{d}_{\mathrm{XY}}\right)$ katsayısının yüksek olabilirlik tahmincisi eşitlik 10 'da belirtilmiştir.

$$
\widehat{d}_{X Y}=\frac{C-D}{C+D+T_{X}}=\frac{2(C-D)}{n^{2}-\sum_{i=1}^{!} n_{+j}^{2}}
$$

11. Adım: Somer D ilişki katsayısının belirlenmesi ( $\widehat{d}$ )

Multinominal örnekleme modeline bağlı olarak $\widehat{d}$ katsayısınınen yüksek olabilirlik tahmincisi eşitlik 10 'da belirtilmiştir.

$$
\widehat{d}=\frac{2(C-D)}{n^{2}-\frac{1}{2}\left(\sum_{i=1}^{1} n_{i+}^{2}+\sum_{i=1}^{1} n_{+j}^{2}\right)}
$$

\subsection{DEMATEL Yöntemi}

Birbirleri ile karşılıklı olarak ilişki içinde olan değişkenlerin ilişki yapısı içinde etkileme (ilişkisel yapıya katkı), etkilenme, ilişkisel yoğunluk ve ilişkisel niteliği (etkileyen veya etkilenen) DEMATEL çok kriterli karar verme yöntemi ile tespiti yapılabilmektedir (Paksoy, 2017b: 63; Çelikbilek, 2018: 5). Dolayısıyla DEMATEL yönteminde değişkenlerin birbirleri ile olan ilişki yapısı içinde "etkileyen" niteliğine sahip olan değişken veya değişkenler sebep, söz konusu ilişkisel yapıda "etkilenen" niteliğine sahip olan değişkenler ise sonuç özelliğine sahiptir (Kaya ve Karaşan, 2020: 118). DEMATEL yöntemi ile birçok teknik ve sosyal problemlerde başarılı uygulamalar sağlanmıştır. DEMATEL yöntemi ile değişkenler arasındaki ilişki yapısı tespit edilmesinin yanında, değişkenlerin önemlilik değerleri de hesaplanabilmektedir (Dinçer, 2019).

DEMATEL yönteminde karar matrisinin hazırlanmasında subjektif anlamda bir uzmanın görüşü veya uzmanların görüşleri alınarak değişkenlerin birbirlerine olan etki değerleri belirlenebilmektedir (Ecer, 2020: 
65). Somer D ilişki katsayısı haricinde değişkenlerin birbirlerine olan etki değerlerini hesaplayan simetrik olmayan Lambda, Goddman ve Kruskal Tau ile belirsizlik katsayısı gibi başka ilişki katsayılarıda bulunmaktadır. Fakat söz konusu ilişki katsayıları ile değişkenler arası ilişki ölçüm sonuçları birbirinden farklı olabilmektedir (Karagöz, 2010a). Dolayısıyla bütünsel (holistic) anlamda simetrik olmayan ilişki katsayılarını düşündüğümüzde, değişkenlerin birbirlerine olan etki değerlerini hesaplayan simetrik olmayan ilişki katsayıları birbirinden farklı sonuçlar çıkarması açısından sübjektif, kendi içinde ise objektif bir özellik kazanmaktadır.

DEMATEL yönteminde doğrudan karar matrisi oluşturulması için ilk olarak bileşenlerin birbirlerine olan etki değerlerinin tespit edilmesi gerekmektedir (Dinçer, 2020: 69). Bu kapsamda DEMATEL yönteminin doğrudan ilişki matrisini sağlamak için bileşenlerin etki değerleri Somer $D$ ilişki katsayısı ile hesaplanabilmektedir (Altıntaş, 2020: 379). Çünkü Somer D ilişki katsayısında, iki değişken arasındaki ilişki yapısında değişkenler bağımlı ve bağımsız değişken olarak tasniflenebilmektedir (Karagöz, 2010b; Demir, 2020: 39). DEMATEL yöntemi ile bileşenler arasındaki ilişkilerde nedensel ilişki temelli yapısal bir model oluşturulabilmekte (problemin çözümünde neden-sonuç ilişkisinin kurulması) ve bileşenlerin etkileme, etkilenme, ilişkisel yoğunluk değerleri hesaplanabilmektedir (Ecer, 2019: 66). Dolayısıyla SPI'yı oluşturan boyutlar ve bileşenler arasındaki ilişki yapısının tespitinde Somer D temelli DEMATEL yöntemi uygulanmıştır. Buna ilişkin olarak DEMATEL yöntemleri uygulama aşamaları aşağıda açıklanmıştır (Tsai ve Chau, 2009; Ayçin, 2019: 92-99; Altan ve Altan, 2020: 86-94).

1. Adım Doğrudan ilişki (etki değerleri) matrisinin oluşturulması

$$
D=\left[\begin{array}{ccc}
d_{11} & d_{1 j} & d_{1 n} \\
\vdots & \vdots & \vdots \\
d_{i 1} & d_{i j} & d_{i n} \\
\vdots & \vdots & \vdots \\
d_{n 1} & d_{n j} & d_{n n}
\end{array}\right]
$$
açıklar.

Doğrudan ilişki matrisinde yer alan değerler, i. değişkenin j. değişken üzerindeki doğrudan ilişkisini

\section{Adım: Normalize Karar Matrisinin Oluşturulması}

Doğrudan ilişki matrisindeki tüm değerler, satır ve sütun toplamlarındaki en büyük değere bölünerek normalleştirme işlemi yapılır. Normalleştirilmiş karar matrisi, toplam etki matrisinin oluşturulmasında kullanılır. Normalleştirme işlemi için eşitlik 13 ve eşitlik 14 'den yararlanılır.

$\mathrm{x}=\mathrm{s}$. $\mathrm{D}$

$s=\min \left[\frac{1}{\max _{i} \sum_{j=1}^{n}\left|d_{i j}\right|}, \frac{1}{\max _{j} \sum_{j=1}^{n}\left|d_{i j}\right|}\right]$

\section{Adım: Toplam Etki Matrisinin Oluşturulması}

Eşitlik $15^{\prime}$ de belirtilen denklem, eşitlik 16 'da açıklanan matrise dönüştürülür. Toplam etki matrisi, normalize edilmiş doğrudan ilişki matrisinin birim matristen çıkartılıp tersi alındıktan sonra tekrar kendisi ile çarpılarak toplam etki matrisi oluşturulur. Dolayısıyla toplam etki matrisi, normalize edilmiş karar matrisi ile olan ilişkileriyle ölçülür.

$$
T=X+X^{2}+\ldots+X^{h}=X(1-X)^{-1}
$$


$T=\left[\begin{array}{ccc}t_{11} & t_{1 j} & t_{1 n} \\ \vdots & \vdots & \vdots \\ t_{i 1} & t_{i j} & t_{i n} \\ \vdots & \vdots & \vdots \\ t_{n 1} & t_{n j} & t_{n n}\end{array}\right]$

4.Adım: Etkileme Değerlerinin Tespit Edilmesi $\left(\mathrm{d}_{\mathrm{i}}\right)$

$d_{i}=\sum_{j=1}^{n} t_{i j} \rightarrow D=\left[\begin{array}{c}d_{1} \\ \vdots \\ d_{j} \\ \vdots \\ d_{n}\end{array}\right]_{n \times 1}$

5.Adım: Etkilenme Değerlerinin Tespit Edilmesi $\left(r_{i}\right)$

$r_{j}=d_{i}=\sum_{j=1}^{n} t_{i j} \rightarrow R=\left[\begin{array}{lllll}r_{1} & \cdots & r_{j} & \cdots & r_{n}\end{array}\right]_{1 \times n}$

6.Adım: illişkisel Yoğunluğun $\left(d_{i}+r_{j}\right)$ ve $d_{i}-r_{j}$ Tespit Edilmesi

$d_{i}+r_{j}$ değeri yüksek olan değişkenin diğer değişkenler ile daha çok ilişki olduğu, buna karşın $d_{i}+r_{j}$ değeri düşük olan değişkenin ise diğer değişkenler ile daha az ilişkili olduğu değerlendirilir.

$d_{i}+r_{j}$

$d_{i}-r_{j}$

7.Adım: Değişkenlerin "Etkileyen" Niteliğinin Belirlenmesi

$d_{i}-r_{j}$ değeri 0 değerinden büyük ise değişkenler etkileyen niteliği kazanır.

$d_{i}-r_{j}>0$ ise

8. Adım: Değişkenlerin “Etkilenen” Niteliğinin Belirlenmesi

$d_{i}-r_{j}$ değeri 0 değerinden küçük ise değişkenler etkilenen niteliği kazanır.

$d_{i}-r_{j}<0$ ise

9. Adım: Eşik Değerinin Belirlenmesi

Uygun bir etkin yönlü diyagram oluşturmak ve doğru karar almak için uygun bir eşik değerine gereksinim duyulur. Eşik değeri, katılımcılar ile yapılan görüşmeler ile tespit edilebileceği gibi araştırmacılar tarafından da belirlenebilir. Çoğu zamanda katılımcıları bir araya getirmek zor bir durumdur. Nesnel anlamda ise eşik değeri toplam ilişki matrisi (T) değerlerinin aritmetik ortalaması ile hesaplanır.

10. Adım: Kriter Ağırlıklarının Hesaplanması

$$
\begin{aligned}
& w_{i a}=\sqrt{\left(D_{i}+R_{i}\right)^{2}+\left(D_{i}-R_{i}\right)^{2}} \\
& w_{i}=\frac{w_{i a}}{\sum_{i=1}^{n} w_{i a}}
\end{aligned}
$$




\section{Bulgular}

DEMATEL yönteminde ilk olarak karar matrisi değerleri ile eşitlik (12) kullanılarak doğrudan ilişki matrisinin belirlenmesi gerekmektedir. Doğrudan ilişki matrisini oluşturan bileşenlerin birbirlerine olan etki değerleri, Tablo 2'de gösterilen karar matrisi değerleri üzerinden Somer D ilişki katsayısı kapsamında eşitlik (9) ve eşitlik (10)'da belirtildiği gibi hesaplanmıştır. Ayrıca bileşenlerin Somer D etki katsayıları SPSS 22 programı ile de ölçülmüştür. Buna göre eşitlik (1)'den eşitlik (11)'e kadar uygulanan yöntem kapsamında tespit edilen değerlerin, SPSS 22 programı ile tespit edilen değerler ile tutarlı olduğu gözlenmiştir. Söz konusu bileşenlere ait karar matrisi Tablo 2'de ve doğrudan ilişki matrisi eşitlik (12) ile belirlenerek Tablo 3'de gösterilmiştir.

Tablo 2. Karar Matrisi

\begin{tabular}{|c|c|c|c|c|c|c|c|c|c|c|c|c|}
\hline Faktörler & \multicolumn{4}{|c|}{ Temel İnsani İhtiyaçlar } & \multicolumn{4}{|c|}{ Refahın Temelleri } & \multicolumn{4}{|c|}{ Firsatlar } \\
\hline Bileşenler & BTTB & ST & BAR & KG & TBE & BHE & SAĞ & ÇK & $\mathrm{BH}$ & BÖSH & KAP & IEE \\
\hline Almanya & 98,92 & 99,56 & 97,43 & 88,63 & 97,51 & 89,46 & 83,48 & 85,65 & 9,44 & 90,4 & 5,84 & 83,42 \\
\hline Avusturya & 8,7 & 99,03 & 97,76 & 88,6 & 8,6 & 92,53 & 86,11 & 90,12 & 9,49 & 8,33 & 4,48 & 81,23 \\
\hline Belçika & 3,42 & 99,59 & 97,54 & 80,48 & 5,3 & 87,03 & 35,6 & 89,29 & 617 & 7,83 & $\underline{5,28}$ & 80,99 \\
\hline Bulgaristan & 95,98 & 97,66 & 90,18 & 9,7 & 87,28 & 81,28 & 64,61 & 79,59 & 107 & 14 & 7,44 & 68,24 \\
\hline Çekya & 98,28 & 98,85 & 95,88 & 88,8 & 99,01 & 8 & 80,11 & 84,51 & 92,34 &, 22 & 0,51 & 77,26 \\
\hline Danimarka & 98,52 & 99,67 & 97,61 & 88,63 & 97,02 & 9 & 83,19 & 88,71 & 96,2 & 91 & 38 & 83,11 \\
\hline Estonya & 97,51 & 96,52 & 98,05 & 80,24 & 97,89 & 9 & 78,18 & 93,78 & 93,7 & 93 & 11 & 73,22 \\
\hline Finlandiya & 98,97 & 96,68 & 99 & 87,24 & 97,07 & 9 & 82,18 & 91,5 & 94,21 & 32 & 72 & 83,35 \\
\hline Fransa & 98,47 & 99,49 & 98,44 & 81,52 & 93,43 & 90 & 88,75 & 90,21 & 92 & 6,8 & 38 & 80,38 \\
\hline GKRY & 7,14 & 99,49 & 96,5 & 80,43 & 94,49 & $91, \varepsilon$ & 86,2 & 86,09 & 93 & 19,9 & 38 & 73,54 \\
\hline Hırvatistan & 97,27 & 97,8 & 93,28 & 76,83 & 96,83 & 82,9 & 74,86 & 84,57 & 86, & 74,09 & 7,48 & 70,65 \\
\hline Hollanda & 98,51 & 99,7 & 97,64 & 90,06 & 93,88 & 95,67 & 85,81 & 89,35 & 95,89 & 89,08 & 72,93 & 84,2 \\
\hline İrlanda & 98,58 & 99,34 & 98,2 & 89,18 & 95,6 & 89,5 & 84,87 & 90,09 & 95 & 87,4 & 77,8 & 78,36 \\
\hline İspanya & 98,98 & 99,69 & 98,32 & 84,1 & 89,69 & 90,4 & 87,48 & 91,17 & 94, & 81,76 & 68,95 & 79,4 \\
\hline İsveç & 98,75 & 99,59 & 98,88 & 89,09 & 94,81 & 92, & 87,13 & 89,77 & 96 , & 89,6 & 82,72 & 79,84 \\
\hline İtalya & 98,69 & 99,37 & 97,77 & 76,91 & 92,33 & 86 & 88,23 & 87,29 & 93 & 76,56 & 37 & 77,35 \\
\hline Letonya & 96,82 & 94,77 & 95, & 76,17 & 96,54 & & 70 , & 85, & 94 & 81,06 & 7 & 73,83 \\
\hline Litvanya & 97,06 & 94,65 & 95 & 76 & 95 & 8 & 70 & 84 & 93 & 79,24 & 62 & 74,62 \\
\hline Lüksemburg & 98,71 & 99, & 98, & 86, & 98,99 & 90 & 86 , & 91 & 94 & 89,22 & 4 & 61,19 \\
\hline Macaristan & 97,1 & 97,2 & 94, & 79, & & 77 , & s & 84, & 82 & 77,1 & 52,15 & 69,03 \\
\hline Malta & 97,87 & 99,45 & 96 & 78,95 & 93, & 86 & 84,06 & 87,74 & 88, & 78,86 & 66,65 & 59,66 \\
\hline Polonya & 97,28 & 98,05 & 95, & 87,28 & 94,54 & 84,96 & 74,28 & 80, & 84,17 & 78,09 & 60,12 & 77,05 \\
\hline Portekiz & 98,06 & 98,04 & 98,08 & 88,59 & 89,08 & 87,69 & 832 & 92 , & 05 & 80,96 & 69,67 & 71,84 \\
\hline Romanya & 95,57 & 92,81 & 89,54 & 79,9 & 82,88 & 81,37 & 64,14 & 83,77 & 87,76 & 71,09 & 44,73 & 66,58 \\
\hline Slovakya & 95,75 & 98,49 & 95,1 & 86,2 & 92,29 & 85,26 & 71,73 & 82,63 & 89,01 & 78,39 & 53,44 & 69,48 \\
\hline Slovenya & 97,62 & 98,52 & 97,36 & 89 & 98,9 & 86,44 & 81,21 & 88,86 & 94,73 & 80,52 & 64,03 & 74,91 \\
\hline Yunanistan & 98,26 & 99,38 & 96,53 & 80,96 & 88,43 & 83,78 & 82,17 & 86,06 & 88,57 & 70,98 & 71,04 & 83,25 \\
\hline
\end{tabular}


Tablo 3. Doğrudan iliş̧ki Matrisi

\begin{tabular}{|c|c|c|c|c|c|c|c|c|c|c|c|c|}
\hline Faktörler & \multicolumn{4}{|c|}{ Temel İnsani İhtiyaçlar } & \multicolumn{4}{|c|}{ Refahın Temelleri } & \multicolumn{4}{|c|}{ Firsatlar } \\
\hline Bileşenler & ВТTВ & ST & BAR & KG & TBE & BHE & SAĞ & ÇK & BH & BÖSH & KAP & IEE \\
\hline BTTB & 0 & 501 & 647 & 0,376 & 0,242 & 4 & 607 & 47 & 442 & 27 & 0,67 &, 487 \\
\hline ST & 506 & 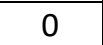 & 391 & 358 & 0,069 & 443 & 592 & 276 & 368 & 25 & 511 & 52 \\
\hline BAR & 65 & 39 & & 30 & 0,158 & 63 & 522 & 0 , & 138 & 1 & 93 & 31 \\
\hline KG & 7 & 359 & 303 & & 0,2 & 363 & 34 & 0, & 7 & 1 & 83 & 4 \\
\hline TBE & 242 & - & 77 & 0,1 & & 0,2 & 6 & 0, & & & & \\
\hline BHE & 486 & 44 & 629 & 0,363 & 0,223 & & 0,503 & 0,577 & 434 & 54 & 514 & 0, \\
\hline SAĞ & 607 & 587 & 618 & 0,234 & 0,066 & 0,5 & & 0,476 & 0,345 & 0,396 & 59 & 0,3 \\
\hline ÇK & 47 & 0,274 & 1 & 0,205 & 0,191 & 0,57 & 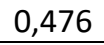 & & 02 & 6 & 13 & 0 , \\
\hline 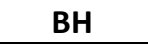 & 442 & 0, & 0 & 0,3 & 0,231 & 0,4 & 0,3 & 0,4 & & 0,595 & 1 & \\
\hline BÖSH & 52 & 0,422 & 0,499 & 0. & $0,4 C$ & 0,5 & 0 & 0,3 & 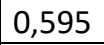 & & 0,504 & \\
\hline KAP & 67 & 0,507 & 0.5 & 0,3 & 0 & 0,5 & 0,459 & 0,459 & 1 & 4 & & 0,476 \\
\hline & $0,4 \varepsilon$ & 0,35 & י & 0,3 & 0,1 & 0,4 & 0,3 & 0,3 & 0,3 & 7 & & \\
\hline$\sum_{\text {sütun }}$ & 5,46 & 4,272 & 5,3 & 2 & 2,089 & 5,1 & 4,6 & 4,5 & & & 4 & 4,0 \\
\hline$\sum_{\text {satır }}$ & 5,453 & 4,301 & 5,392 & 3,57 & 2,085 & 5,140 & 4,634 & 4,342 & 4,508 & 5,156 & 5,221 & 4,131 \\
\hline
\end{tabular}

Not: Analizde 0,344 ile 0,502 arasındaki değerler $p .<05,0,502$ ile 0,999 arasındaki değerler ise $p .<01$ değerinde anlamlıdır.

Tablo 2'de belirtilen doğrudan ilişki matrisinin satır bileşenleri bağımsız değişkenler, sütun bileşenleri ise bağımlı değişkenler olarak tasniflenmiştir. Örneğin Tablo2'ye göre, BTTB bileşeni ST'yi 0,501, ST ise BTTB'yi 0,506 değerinde etkilemiştir. İkinci adım olarak normalize karar matrisi eşitlik (13) ve eşitlik (14) yardımıyla hesaplanarak Tablo 4'de belirtilmiştir.

Tablo 4. Normalize Karar Matrisi

\begin{tabular}{|c|c|c|c|c|c|c|c|c|c|c|c|c|}
\hline Bileşenler & BTTB & ST & BAR & KG & TBE & BHE & SAĞ & ÇK & BH & BÖSH & KAP & IEE \\
\hline BTTB & 0 & 0,092 & 0,118 & 0,069 & 0,044 & 0,089 & 0,111 & 0,086 & 0,081 & 0,096 & 0,123 & 0,089 \\
\hline ST & 0,093 & 0 & 0,072 & 0,066 & 0,013 & 0,081 & 0,108 & 0,051 & 0,067 & 0,078 & 0,094 & 0,066 \\
\hline BAR & 0,119 & 0,071 & 0 & 0,056 & 0,029 & 0,115 & 0,114 & 0,133 & 0,08 & 0,092 & 0,109 & 0,07 \\
\hline KG & 0,069 & 0,066 & 0,055 & 0 & 0,037 & 0,066 & 0,043 & 0,038 & 0,069 & 0,075 & 0,07 & 0,065 \\
\hline TBE & 0,044 & 0,012 & 0,029 & 0,036 & 0 & 0,041 & 0,012 & 0,035 & 0,042 & 0,074 & 0,026 & 0,03 \\
\hline BHE & 0,089 & 0,081 & 0,115 & 0,066 & 0,041 & 0 & 0,092 & 0,106 & 0,079 & 0,101 & 0,094 & 0,076 \\
\hline SAĞ & 0,111 & 0,107 & 0,113 & 0,043 & 0,012 & 0,092 & 0 & 0,087 & 0,063 & 0,072 & 0,084 & 0,063 \\
\hline ÇK & 0,086 & 0,05 & 0,132 & 0,038 & 0,035 & 0,105 & 0,087 & 0 & 0,074 & 0,072 & 0,076 & 0,04 \\
\hline BH & 0,081 & 0,067 & 0,08 & 0,069 & 0,042 & 0,079 & 0,063 & 0,074 & 0 & 0,109 & 0,095 & 0,066 \\
\hline BÖSH & 0,096 & 0,077 & 0,091 & 0,075 & 0,074 & 0,101 & 0,072 & 0,072 & 0,109 & 0 & 0,092 & 0,082 \\
\hline KAP & 0,123 & 0,093 & 0,108 & 0,07 & 0,026 & 0,094 & 0,084 & 0,084 & 0,095 & 0,092 & 0 & 0,087 \\
\hline IEE & 0,089 & 0,066 & 0,069 & 0,065 & 0,03 & 0,076 & 0,063 & 0,063 & 0,066 & 0,082 & 0,087 & 0 \\
\hline
\end{tabular}

DEMATEL yöntemi ile eşitlik (15) ve eşitlik (16) kapsamında birim matris ile normalize matris farkı (1$X)$, birim matris ile normalize matris farkının çarpma işlemine göre tersi $(1-X)^{-1}$ ve toplam etki matrisi $(T=X(1-$ $X)^{-1}$ ) tespit edilmiştir. Buna göre tespit edilen $(1-X),(1-X)^{-1}$ ve $X(1-X)^{-1}$ değerleri Tablo $5^{\prime}$ de sunulmuştur. 
F. F. Altintas

Tablo 5. Birim Matris ile Normalize Matris farkı, Birim Matris ile Normalize Matris Farkının Çarpma İ̧lemine Göre Tersi ve Toplam Etki Matrisleri

\begin{tabular}{|c|c|c|c|c|c|c|c|c|c|c|c|c|}
\hline \multicolumn{13}{|c|}{ (I-X) Matrisi } \\
\hline Bileşenler & BTTB & ST & BAR & KG & TBE & BHE & SAĞ & ÇK & $\mathrm{BH}$ & BÖSH & KAP & IEE \\
\hline BTTB & 1 & $-0,09$ & $-0,12$ & $-0,07$ & $-0,04$ & $-0,09$ & $-0,11$ & $-0,09$ & $-0,08$ & $-0,1$ & $-0,12$ & $-0,09$ \\
\hline ST & $-0,09$ & 1 & $-0,07$ & $-0,07$ & $-0,01$ & $-0,08$ & $-0,11$ & $-0,05$ & $-0,07$ & $-0,08$ & $-0,09$ & $-0,07$ \\
\hline BAR & $-0,12$ & 0,07 & 1 & $-0,06$ & $-0,03$ & $-0,12$ & $-0,11$ & $-0,13$ & $-0,08$ & $-0,09$ & $-0,11$ & $-0,07$ \\
\hline KG & $-0,07$ & $-0,07$ & $-0,06$ & 1 & $-0,04$ & $-0,07$ & $-0,04$ & $-0,04$ & $-0,07$ & $-0,08$ & $-0,07$ & $-0,06$ \\
\hline TBE & $-0,04$ & $-0,01$ & $-0,03$ & $-0,04$ & 1 & $-0,04$ & $-0,01$ & $-0,03$ & $-0,04$ & $-0,07$ & $-0,03$ & $-0,03$ \\
\hline BHE & $-0,09$ & $-0,08$ & $-0,12$ & $-0,07$ & $-0,04$ & 1 & $-0,09$ & $-0,11$ & $-0,08$ & $-0,1$ & $\begin{array}{l}-0,09 \\
\end{array}$ & $-0,08$ \\
\hline SAĞ & $-0,11$ & $-0,11$ & $-0,11$ & $-0,04$ & $-0,01$ & $-0,09$ & 1 & $-0,09$ & $-0,06$ & $-0,07$ & $-0,08$ & $-0,06$ \\
\hline ÇK & $-0,09$ & $-0,05$ & $-0,13$ & $-0,04$ & $-0,03$ & $-0,11$ & $-0,09$ & 1 & $-0,07$ & $-0,07$ & $-0,08$ & $-0,04$ \\
\hline $\mathrm{BH}$ & $-0,08$ & $-0,07$ & $-0,08$ & $-0,07$ & $-0,04$ & $-0,08$ & $-0,06$ & $-0,07$ & 1 & $-0,11$ & $-0,1$ & $-0,07$ \\
\hline BÖSH & $-0,1$ & $-0,08$ & $-0,09$ & $-0,08$ & $-0,07$ & $-0,1$ & $-0,07$ & $-0,07$ & $-0,11$ & 1 & $-0,09$ & $-0,08$ \\
\hline KAP & $-0,12$ & $-0,09$ & $-0,11$ & $-0,07$ & $-0,03$ & $-0,09$ & $-0,08$ & $-0,08$ & $-0,1$ & $-0,09$ & 1 & $-0,09$ \\
\hline IEE & $-0,09$ & $-0,07$ & $-0,07$ & $-0,06$ & $-0,03$ & $-0,08$ & $-0,06$ & $-0,06$ & $-0,07$ & $-0,08$ & $-0,09$ & 1 \\
\hline \multicolumn{13}{|c|}{$(1-X)^{-1}$ Matrisi } \\
\hline Bileşenler & BTTB & ST & BAR & KG & TBE & BHE & SAĞ & ÇK & BH & BÖSH & KAP & IEE \\
\hline BTTB & 1,589 & 0,559 & 0,693 & 0,452 & 0,272 & 0,637 & 0,619 & 0,58 & 0,565 & 0,633 & 0,675 & 0,523 \\
\hline ST & 0,564 & 1,388 & 0,545 & 0,378 & 0,2 & 0,526 & 0,521 & 46 & 0,462 & 0,515 &, 546 & 0,422 \\
\hline BAR & 0,696 & 42 & 1,591 & 0,441 & 0,259 & 0,661 & 0,623 & 62 & 0,565 & 629 & 664 & 0,507 \\
\hline KG & 0,454 & 0,376 & 0,441 & 1,259 & 0,189 & 0,43 & 0,385 & 7 & 0,391 & 433 & 441 & 0,355 \\
\hline TBE & 0,271 & 8 & 0,258 & 0,188 & 1,093 & 0,256 & 0,215 & 3 & 0,234 & 284 & 247 & 0,202 \\
\hline BHE & 0,639 & 3 & 0,66 & 0,429 & 0,257 & 1,527 & 0,576 & 0,57 & 0,538 & 0,608 & 0,621 & 0,488 \\
\hline SAĞ & 0,619 & 0,51 & 0,62 & 0,383 & 0,215 & 0,574 & 1,46 & 0,52 & 0,491 & 0,547 & 0,576 & 0,448 \\
\hline ÇK & 0,565 & 9 & 0,604 & 0,356 & 0,224 & 0,555 & 0,509 & 1,42 & 0,472 & 517 &, 537 & 0,403 \\
\hline U & 0,565 & 0 & 0,563 & 0,389 & 0,234 & 0,537 & 0,491 & 49 & & 554 &, 558 & 0,431 \\
\hline BÖSH & 0,633 & 0 & 0,627 & 0,431 & 0,284 & 0,607 & 0,547 & 53 & 0,554 & 508 & ,609 & 0,486 \\
\hline KAP & 0,679 & & 0,666 & 0,442 & 0,249 & 0,624 & 0,581 & 0 & 0,562 & 613 & 1,548 & 0,508 \\
\hline IEE & 0,536 & 0,429 & 0,518 & 0,362 & 0,208 & 0,5 & 0,46 & 0,45 & & 0,497 & 0,517 & 1,342 \\
\hline \multicolumn{13}{|c|}{ Toplam Etki Matrisi $\mathrm{X}(1-\mathrm{X})^{-1}$} \\
\hline Bileşenle & TTB & 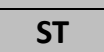 & $\mathbf{R}$ & KG & TBE & BHE & SAĞ & ḩ & B & BÖSH & KAP & IEE \\
\hline BTTB & 0,589 & 0,559 & 0,6 & 0,452 & 0,272 & 0,637 & 0,619 & 0,58 & 0,565 & 0,633 & 0,675 & 0,523 \\
\hline ST & 0,564 & 0 & 0 & 0,378 & 8 & 0,526 & 0,521 & . & 0,2 & 515 & 0,546 & 0,422 \\
\hline $\mathrm{B}$ & & & & & 0,259 & 0,661 & 0,623 & & & 29 & 664 & 0,507 \\
\hline- & & & & & & & & & & & 441 & 0,355 \\
\hline & & & & & & & & & & 34 & 247 & 0,202 \\
\hline & & & & 0,429 & 0,257 & 0,527 & 0,576 & & 0,538 & 0,608 & 0,621 & 0,488 \\
\hline SAĞ & & & & 0,383 & 0,215 & 0,574 & 0,46 & & 0,491 & 0,547 & 0,576 & 0,448 \\
\hline- & & & & & 0,224 & 0,555 & 0,509 & & 0,472 & & 0,537 & 0,403 \\
\hline & & & & & & 0,537 & 491 & & & 554 & 558 & 0,431 \\
\hline BÖSH & 0,633 & 0,511 & 0,627 & 0,431 & 0,284 & 0,607 & 0,547 & 0,53 & 0,554 & 0,508 & 0,609 & 0,486 \\
\hline KAP & & & 0,666 & 0,442 & 0,249 & 0,624 & 0,581 & 0,56 & 0,562 & 0,613 & 0,548 & 0,508 \\
\hline IEE & 0,536 & 0,429 & 0,518 & 0,362 & 0,208 & 0,5 & 0,46 & 0,45 & 0,441 & 0,497 & 0,517 & 0,342 \\
\hline
\end{tabular}

DEMATEL yöntemi ile son olarak bileşenler arasındaki ilişki yapısında etkilenen ve etkileyen niteliğine sahip bileşenlerin tespit edilir. Bu kapsamda eşitlik (17), eşitlik (18), eşitlik (19) ve eşitlik (20) kapsamında belirlenen değerler Tablo 6'da açıklanmıştır. 
Tablo 6. Bileşenlerin İlişkisel Yapıya Katkı, Bileşenlerin İlişkisel Yapıda Etkilenme, Yoğunluk ve Nitelik Değerleri

\begin{tabular}{|c|c|c|c|c|c|}
\hline Boyutlar & Bileşenler & $d_{i}$ & $r_{j}$ & $d_{i}+r_{j}$ & $d_{i}-r_{j}$ \\
\hline \multirow{5}{*}{ Tíg } & BTTB & 6,8000 & 6,8107 & 13,611 & $-0,0107$ \\
\hline & ST & 5,5239 & 6,2215 & 11,745 & $-0,6977$ \\
\hline & BAR & 6,8003 & 5,6577 & 12,458 & 1,1426 \\
\hline & KG & 4,5242 & 4,9618 & 9,4859 & $-0,4376$ \\
\hline & Ortalama & 5,9121 & 5,9129 & 11,825 & ----- \\
\hline \multirow{5}{*}{ RT } & TBE & 2,6771 & 11,307 & 13,984 & $-8,6303$ \\
\hline & BHE & 6,437 & 16,560 & 22,997 & $-10,123$ \\
\hline & SAĞ & 5,9721 & 22,721 & 28,693 & $-16,749$ \\
\hline & ÇK & 5,5994 & 26,627 & 32,226 & $-21,027$ \\
\hline & Ortalama & 5,1714 & 19,304 & 24,475 & ----- \\
\hline \multirow{5}{*}{ FR } & BH & 5,6755 & 28,739 & 34,415 & $-23,064$ \\
\hline & BÖSH & 6,3312 & 34,611 & 40,942 & $-28,280$ \\
\hline & KAP & 6,5806 & 39,950 & 46,531 & $-33,369$ \\
\hline & İEE & 5,2563 & 44,870 & 50,126 & $-39,614$ \\
\hline & Ortalama & 5,9609 & 37,043 & 43,003 & ----- \\
\hline
\end{tabular}

Tablo $6^{\prime}$ da belirtilen $d_{i}$, bileşenlerin ilişkisel yapıya katkı değerini (etkileme değerini), $r_{j}$ bileşenlerin iliş̧isel yapıda etkilenme değerini, $d_{i}+r_{j}$ bileşenlerin ilişkisel yapıdaki ilişkisel yoğunluk değerini (etkileme+etkilenme) ve son olarak $d_{i}-r_{j}$ bileşenlerin ilişkisel yapıda hangi niteliğe (etkileyen veya etkilenen) sahip olduğunu göstermektedir. Tablo $\sigma^{\prime}$ da belirtilen boyutların $d_{i}, r_{j}$ ve $d_{i}+r j$ değerleri boyutlara bağlı bileşenlerin aritmetik ortalamaları hesaplanarak tespit edilmiştir. Tablo 6'ya göre, ilişkisel yapıya katkı sağlayan boyutların değerleri $F R\left(d_{i=F R}=5,9609\right)$, TiG $\left(d_{i=T i G}=5,9121\right)$ ve $R T$ ( $\left.d_{i=R T} 5,1714\right)$ olarak sıralanmıştır. Buna göre, FR ile TiG boyutları arasında ilişkisel yapıya katkı sağlamaları değerleri arasında belirgin farklılık bulunmazken, buna karşın RF boyutunun diğer boyutlar ile ilişkisel yapıya katkı sağlamaları değerleri arasında belirgin farklııkları bulunmaktadır. Bileşenler kapsamında ise boyutlar arasındaki ilişkiye en fazla katkı sağlayan bileşenlerin BAR $\left(\mathrm{d}_{i=B A R}=6,8003\right)$ ve BBTB $\left(\mathrm{d}_{i=B \mathrm{~B} T \mathrm{~B}}=6,8000\right)$, boyutlar arasındaki ilişkiye en az katkı sağlayan bileşenin ise TBE $\left(d_{i=T B E}=2,7148\right)$ olduğu tespit edilmiştir. Ayrıca DEMATEL yöntemi kapsamında eşik değeri 0,4734 ( $\alpha=0,4734)$ olarak hesaplanmıştır. Bu değeri aşan yalnızca BAR bileşenin olduğu tespit edilmiştir $\left(\alpha_{B A R}=1,1426>\alpha=0,4734\right)$.

Tablo 6 değerlendirildiğinde, FR boyutunun diğer sosyal gelişim boyutları olan Tíg ve RT boyutlarından ilişkisel yapıya daha katkı sağlaması, boyutların birbirlerini tamamlamasında Avrupa Birliğin ülkeleri için FR boyutunun diğer boyutlara göre öncelikli ve önemli olduğunu açıklamaktadır. Dolayısıyla Avrupa Birliği ülkeleri için FR boyutunun TiG ve RT boyutları üzerinde onarıcı faaliyetlerinin işlevselliğinin daha fazla olduğu değerlendirilebilir.

Tablo 6 incelendiğinde, boyutlar arası ilişkilerde boyutların etkilenme değerleri $F R\left(r_{j=F R}=37,043\right)$, TiG $\left(r_{j=T i G}=19,304\right)$ ve $R T\left(r_{j=R T}=5,9129\right)$ olarak sıralanmıştır. Değerlere göre FR boyutunun diğer boyutlar arasında etkilenme niceliği olarak belirgin farklııkları bulunmaktadır. Dolayısıyla bu durum, FR boyutunun TiG ve RT boyutları tarafından sağlanma derecesinin, TiG ve RT boyutlarının birbirlerini ve FR boyutunu sağlama derecelerinden yüksek olduğunu göstermektedir. Aynı zamanda FR boyutunun diğer boyutlara göre diğer boyutlardan etkilenme derecesinin fazla olması, Avrupa Birliği ülkelerinin TiG ve RT kapsamında yapılan faaliyetlerin FR kapsamında yapılan faaliyetleri güçlendirdiği düşünülebilir.

Tablo 6'ya göre, sosyal gelişim boyutları arasındaki ilişkisel yapıda ilişkisel yoğunluk değerleri FR $\left(d_{i}+r_{j=R}=43,003\right)$, TiG $\left(d_{i}+r_{j}=T i G=24,475\right)$ ve $R T\left(d_{i}+r_{j}=11,825\right)$ olarak sıralanmıştır. Söz konusu nicelikler değerlendirildiğinde, FR boyutunun diğer boyutlar ile ilişkisel yoğunluk olarak belirgin farklılıkları bulunmaktadır. Bu durum ise Avrupa Birliği ülkelerinin sosyal gelişme faaliyetleri kapsamında FR boyutunun TiG ve RT boyutlarından, TiG ve RT boyutlarının birbirinden ve FR boyutundan faydalandığından daha çok 
faydalandığını açıklamaktadır. Ayrıca FR boyutunun TiG ve RT boyutlarına, TiG ve RT boyutlarının birbirine ve FR boyutuna sağladığı faydalardan daha çok fayda sağlamaktadır.

Tablo $6^{\prime}$ da son olarak $d_{i}-r_{j}$ değerleri bileşenlerin ilişkisel yapıda etkileyen veya etkilenen niteliğine sahip olduğunu göstermektedir. Tablo 6'ya göre, 12 sosyal gelişim bileşenin içinden ilişkisel yapıda sadece BAR bileşeninin "etkileyen", diğer 11 bileşenin ise "etkilenen" niteliğe sahip olduğu tespit edilmiştir. Bunun sebebi, BAR bileşeninin diğer bileşenlere kıyasla diğer bileşenlere toplam etki değerinin, diğer bileşenlerden toplam etkilenme değerinden fazla olmasından kaynaklanmaktadır. Boyutsal olarak değerlendirildiğinde, TiG boyutuna ait bileşenlerin diğer boyutlara ait bileşenlere göre etkileme niteliğine daha çok yakındır. Dolayısıyla TiG boyutu kendi ilişki kapasitesine göre diğer boyutlara kıyasla ilişkisel yapı içinde bağımsız değişken olma işlevselliği daha önceliklidir.

\section{Sonuç}

Sonuçlara göre, TiG, RT ve FR sosyal gelişme boyutlarının birbirleri arasındaki ilişkisel yapıya en fazla katkı sağlayan boyutun FR olduğu tespit edilmiştir. Böylelikle bu durum, Avrupa Birliği ülkelerinin FR boyutu ile TiG ve RT boyutları üzerinden yapmış olduğu faaliyetlerin sonuçsal nitelikleri, TiG ve RT boyutlarının birbirlerinin ve FR boyutu üzerinden yapmış oldukları faaliyetlerin sonuçsal niteliklerinden daha anlamlı olduğunu göstermektedir. Başka bir ifade ile Avrupa Birliği ülkelerinin FR boyutu kapsamında yaptığı beslenme ve temel tıbbi bakım, su ve temizlik, barınma ve kişisel güvenlik konularında faaliyetleri, TiG boyutu kapsamında yapılan temel bilgiye erişim, bilgiye ve haberleşmeye erişim, sağlık, çevre kalitesi ve RT boyutu kapsamında yapılan bireysel haklar, bireysel özgürlük ve seçim hakkı, kapsayıcılık ve ileri eğitime erişim bileşenleri üzerinde iyileştirici etkisi bulunmaktadır. Başka bir bulguya göre, söz konusu ilişkisel yapıda etkilenme derecesi en fazla olan boyutun yine FR olduğu gözlenmiştir. Dolayısıyla Avrupa Birliği ülkelerine göre FR boyutunun edilgen niteliği, TiG ve RT boyutlarına göre daha anlamlıdır. Diğer bir deyişle, TíG ve RT boyutlarının FR boyutunu ilgilendiren faaliyetlerin, FR ve TiG boyutlarının RT'yi, FR ve RT boyutlarının TiG boyutunu ilgilendiren faaliyetlerden daha fazla olduğu çıkarımında bulunulabilir.

Ülkelere göre ilişkisel yapıda en fazla ilişkisel yoğunluk değeri fazla olan boyutun FR olduğu belirlenmiştir. Dolayısıyla FR boyutu, diğer boyutlara kıyasla daha geniş ve kapsayıcı bir özelliğe sahiptir. Bunun yanında bulgular çerçevesinde ilişkisel yapıda sadece BAR (barınma) bileşeninin "etkileyen", buna karşın SPI'yı oluşturan diğer 11 bileşenin "etkilenen" niteliğine sahip olduğu tespit edilmiştir. Bu sonuç, BAR bileşeninin TiG boyutuna ait olması kapsamında Maslow'un ihtiyaçlar hiyerarşi teorisi ile tutarlılık göstermektedir. Boyutsal olarak değerlendirildiğinde, BAR bileşeni dışında ilişkisel yapı içinde "etkileyen" niteliğine en yakın olan bileşenlerin TiG boyutunu oluşturan bileşenler olduğu gözlenmiştir. Bu durum, TiG boyutunun ilişki yapısı içinde kendi ilişki potansiyeline göre diğer boyutlara kıyasla bağımsız değişken olma özelliğinin daha öncelikli olduğunu göstermektedir. Bütünsel anlamda araştırma bulgularına göre, FR boyutunun boyutlar arası ilişkisel yapıya en fazla katkı sağlamasından ve ilişkisel yapı içinde etkilenme değerinin ve ilişkisel yoğunluk değerinin diğer boyutlara göre daha fazla olmasından dolayı FR boyutunun diğer boyutlara kıyasla ilişkisel yapı içinde daha çok sebebe ve sonuca odaklanan bir yapısının olduğu sonucuna ulaşılmıştır.

Literatür değerlendirildiğinde, bu araştırma Özgür Güler vd. (2019)'nin araştırmasına hem araştırmanın konusu hem de yöntem açısından büyük benzerlik göstermektedir. Özgür Güler vd. (2019) sadece TiG ile FR boyutu arasındaki ilişki yapısı belirlemiştir. Bu araştırmada ise tüm boyutlar arasındaki ilişkiyi incelenmiştir. Buna göre Özgür Güler vd. (2019)'nin araştırması SPI boyutları arasında ilişkisel yapının tespit edilmesine yönelik bu araştırmaya göre daha spesifik nitelik taşımaktadır. Buna karşın bu araştırmada ise Özgür Güler vd. (2019)'nin araştırmasına kıyasla SPI boyutları arasında ilişkisel yapının belirlenmesine daha bütünsel (holistic) ve kapsamlı olarak yaklaşılmıştır. Yöntem açısından ise Özgür Güler vd. (2019)'nin söz konusu SPI boyutları arasındaki ilişki yapısını kanonik korelasyon yöntemi ile tespit etmiştir. Bu araştırmada ise söz konusu boyutlar arası ilişki yapısı Somer D temelli DEMATEL yöntemi ile belirlenmiştir. Bunların dışında her iki çalışmaya göre "barınma" SPI bileşeninin boyutlar arasındaki ilişkisel yapıya en fazla katkı sağlayan bileşen olması dikkat çekicidir. 
Ülkeler için öneriler kapsamında, Avrupa Birliği ülkeleri öncelikli olarak ilişkisel yapıya en az katkı sağlayan TBE bileşeni olmak üzere diğer tüm bileşenlerinin birbirlerini ilgilendirecek ve tamamlayacak stratejiler ve faaliyetler gerçekleştirerek söz konusu bileşenlerin birbirlerini sağlamasında işlevselliğini artırabilirler. Böylelikle ülkeler, sosyal bileşenler arasındaki ilişkileri güçlendirerek bileşenlerin gelişme performanslarını çoğaltabilirler. Böylelikle ülkeler, sosyal gelişim performanslarını artırmalarıyla sosyal gelişim ile ilişkili olan inovasyon, girişimcilik, lojistik, insani gelişme, refah düzeyi, yaşam standardı, bilim ve teknoloji vb. sosyal ve teknik boyutları küresel anlamda geliştirebilirler. Yöntem bakımından ise SPI'yı oluşturan bileşenler arasındaki ilişkilerin tespitinde, Yapısal Eşitlik Modeli öz yinelemesiz (non-recursive) yönteminden, ilişki katsayılarından, kanonik korelasyondan, regresyon (doğrusal, lojistik), probit ve logit analizlerinden faydalanılarak yöntemler kapsamında hesaplanan ilişki değerleri arasındaki tutarlılıklar ve tutarsızlıklar neden-sonuç analizi çerçevesinde incelenebilir.

\section{Beyan ve Açıklamalar (Declarations and Disclosures)}

Yazarların Etik Sorumlulukları (Ethical Responsibilities of Authors): Bu çalışmanın yazarı, araştırma ve yayın etiği ilkelerine uyduğunu kabul etmektedir.

Çıkar Çatışması (Conflicts of Interest): Yazar tarafından herhangi bir çıkar çatışması beyan edilmemiştir.

Finansal Destek (Funding): Yazar, çalışmanın hazırlanması ve/veya yayınlanması sürecinde herhangi bir finansal destek almamıştır.

Yazar Katkı Oranı (Author Contributions): Yazar; kavramlaştırma ve çalışma dizaynı, verilerin toplanması, verilerin analizi ve sonuçların yorumlanması, çalışmanın ilk/taslak halinin yazılması, çalışmanın gözden geçirilmesi ve düzenlenmesi/düzeltilmesi aşamalarından tek başına sorumlu olduğunu beyan etmektedir.

Intihal Denetimi (Plagiarism Checking): Bu çalışma, intihal tarama programı kullanılarak intihal taramasından geçirilmiştir.

\section{Kaynaklar}

Abdel-Basset, M., Manogaran, G., Gamal, A., \& Smarandache, F. (2018). A hybrid approach of neutrosophic sets and DEMATEL method for developing supplier selection criteria. Des Autom Embed Syst, (22), 257-278.

Albayrak, Ö., \& Erkayman, B. (2018). Bulanık DEMATEL ve EDAS yöntemleri kullanılarak sporcular için akıllı bileklik seçimi. Ergonomi, 1(1),92-102.

Altıntaş, F. F. (2020). Rekabet ve inovasyon boyutları ilişkisinin çok yönlü değerlendirilmesine yönelik ampirik bir araştırma: G20 grubu ülkeleri. Business \& Management Studies: An International Journal, 8(3), 3052-3096.

Atan, M., \& Altan, Ş. (2020). Örnek uygulamalarla çok kriterli karar verme yöntemleri. Ankara: Gazi Kitapevi.

Ayçin, E. (2019). Çok kriterli karar verme. Ankara: Nobel Yayın.

Battal, Ü. (2018). Türkiye'de havayolu taşımacılığının fianansman sorunları: DEMATEL yöntemi uygulaması. Ömer Halisdemir Üniversitesi iktisadi ve Idari Bilimler Fakültesi Dergisi, 11(2), 96-111.

Chang, B., Chang, C. W., \& Wu, C. H. (2011). Fuzzy DEMATEL method for developing supplier selection criteria. Expert Systems with Applications, 38(3), 1850-1858.

Çelikbilek, Y. (2018). Çok Kriterli karar verme yöntemleri. Ankara: Nobel Akademik Yayıncılık.

Çınar, Y. (2013). Kariyer tercihi probleminin yapısal bir modeli ve riske karşı tutumlar: Olasılıklı DEMATEL yöntemi temelli bütünleşik bir yaklaşım. Sosyoekonomi, (19), 157-186.

Çoşkun, S., Özgenç, N., \& Güneş, S. (2015). Sosyal performansın ölçümünde yeni yöntem: Sosyal gelişme endeksi ve Türkiye'nin görünümü. Sosyal Politika Çalışmaları Dergisi, 15(34), 121-153.

Demir, i. (2020). SPSS ile istatistik rehberi. İstanbul: Efe Akademi Yayınları.

Dinçer, S. E. (2019). Çok kriterli karar alma. Ankara: Gece Akademi.

Ecer, F. (2020). Çok kriterli karar verme. Ankara: Seçkin Yayıncılık.

Erkal, M. (1982). Sosyal değişme ve dosyal gelişmeye çağdaş bir yaklaşım. Sosyal Siyaset Konferansları Dergisi(31), 297328. 
Estes, R. J. (1984). The social progress of nations. California: Praeger Publishers.

Jahic, H., \& Cinjarevic, M. (2017). The effect of social progress and education on corruption a contingency theory persfective. Journal of Economics abd Business, 5(1), 19-31.

Jassbi, J., Mohamadnejad, F., \& Nasrollahzade, H. (2011). A fuzzy DEMATEL framework for modeling cause and effect relationships of strategymap. Expert Systems with Applications, 38(5), 5967-5973.

Karaatlı, M., Ömürbek, N., Işık, E., \& Yılmaz, E. (2016). Performans değerlemesinde DEMATEL ve bulanık TOPSIS uygulaması. Ege Akademik Bakış, 16(1), 49-64.

Karagöz, Y. (2010a). ilişki katsayıları (1 b.). Ankara, Türkiye: Detay Yayıncılık.

Karagöz, Y. (2010b). illişki katsayısı ile öğrenci başarı faktörlerinin belirlenmesi. Electronic Journal of Social Sciences, 9(32), 425-446.

Karmowska, G. (2017). Development of the EU societies and social progress. Ekonomia I Srodowisko, 4(63), 178-190.

Kaya, A. (2018). Finansal Pazardaki gelişmelerin insani gelişmişlik üzerine etkisi: Türkiye örneği. International Journal of Economic and Administrative Studies, (20), 170-180.

Kaya, İ., \& Karaşan, A. (2020). Çok kriterli karar verme. İstanbul: Umuttepe Yayınları.

Kubiczek, A. (2014). Jak mierzyc dzis rozwój spoleczno-gospodarczy kraju? Nierównosci Spoleczne a Wzrost Gospodarczy, (38), 40-56.

Morris, M. D. (1980). The physical quality of life Index (PQLI). Development Digest, 18(1), 95-109.

Navarro, V. G., Albornoz, J. M., \& Saldaña, G. N. (2019). Indice DE Progresso Social Cabrero 2019- Avances y Desfios en Materias de Progreso Social. Chile: IPS.

Newson, R. (2002). Parameters behind "nonparametric" statistics:Kendall's tau, Somers' D and median difference. The Stata Journal, 2(1), 45-64.

Oktay, E. (2017). Iliş̧ki ölçüleri. Erzurum: Erzurum Kültür Eğitim Kitap Kırtasiye.

Öksüz, E. (1972). Sosyal gelişme. İstanbul Üniversitesi Iktisat Fakültesi Mecmuası, 32(1-4), 21-41.

Özen Kutanis, R. Ö., Öncü, M. A., Mesci, M., \& Çömlekçi, İ. (2010). 2008-2009 Küresel ekonomik krizinin bankacılık sektöründeki işgörenlere ve örgütlerin performansına etkisi: Erzurum ilinde faaliyet gösteren banka şubelerinde bir araştırma. I. Turgut Özal Uluslararası Ekonomi ve Siyaset Kongresi, Malatya, 623-649

Özgür Güler, E., Güler, H., \& Şanlı, S. (2019). Sosyal gelişme endeksine dayalı temel insani ihtiyaçlar fırsatlar alt endeksleri arasındaki ilişki. Çukurova Üniversitesi Sosyal Bilimler Enstitüsü Dergisi, 28(2), 55-70.

Paksoy, S. (2017a). A DEMATEL method for identifying critical success factors in an implementation of information system project. Eurasian Academy of Sciences Eurasian Econometrics, Statistics \& Emprical Economics Journal, 6, 1-17.

Paksoy, S. (2017b). Çok kriterli karar vermede güncel yaklaşımlar. Adana: Karahan Kitapevi.

Pate, S. K., \& Sweo, R. (2016). The social progress Index in International business site selection: Three case studies. Journal of International Education and Leadership, 6(2), 1-10.

Porter, M. E., Stern, S., \& Green, M. (2014). Social progress index. Washington: Social Progress Imperative.

Porter, M. E., Stern, S., \& Green, M. (2014). Social progress index - methodological report. Washington: Social Progress Imperative.

Porter, M. E., Stern, S., \& Green, M. (2015a). Social progress index. Washington: Social progress imperative .

Porter, M. E., Stern, S., \& Green, M. (2015b). Social progress index - methodological report. Washington: Social Progress Imperative.

Porter, M. E., Stern, S., \& Green, M. (2016). Social progress index. Washington: Social Progress Imperative.

Porter, M., Stern, S., \& Green, M. (2016). Social progress imperative - methodological report. Washington: Social Progress Imperative.

Porter, M., Stern, S., \& Green, M. (2017). Social progress index. Washington: Social progress imperative.

Romero, C. A., Montero, D. O., \& Ruales, L. C. (2017). An approach to social progress index in Ecuador. Economica coyuntural revista de temas de perspectivas y coyuntura, 2(1), 1-29.

Sharma, B. (2003). Hofstede's measures of national culture and social progress. Psychological Reports(92), 1199-1202.

Shieh, J. I., Wu, H. H., \& Huang, K. K. (2010). A DEMATEL method in identifying key success factors of hospital service quality. Knowledge-Based Systems, (23), 277-282. 
Social Progress Imperative, (2018). Social progress index. Washington: Social Porgress Imperative.

Social Progress Imperative, (2019). Social progress index. Washington: Social Progress Imperative.

Social Progress Imperative, (2020). Social progress index. Washington: Social Progress Imperative.

Sökmen, A. (2014). Sosyal gelişme endeksi Türkiye İçin ne ifade ediyor? Tepav - Değerlendirme Raporu, N201421.

Stern, S., \& Epner, T. (2018). Social progress index - methodological report. Washington: Social Progress Imperative.

Stern, S., Wares, A., \& Epner, T. (2017). Social progress index - methodological report. Washington: Social Progress Imperative.

Stern, S., Wares, A., \& Epner, T. (2018). Social progressive index - methodological report. Washington: Social Progress Imperative.

Stern, S., Wares, A., \& Orzell, S. (2015). Social progress imperative - methodological report. Washington: Social Progress Imperative.

Stern, S., Wares, A., Orzell, S., \& O'sillivan, P. (2014). Social progress index 2014 - methodological report. Washington: Social Progress Impearative.

Stiglitz, J. E., Sen, A., \& Fitoussi, J. P. (2008). Report by the Commission on the Measurement of Economic Performance and Social Progress.

Tsai, W. H., \& Chou, W. C. (2009). Selecting management systems for sustainable development in SMEs: A novel hybrid model based on DEMATEL ANP, and ZOGP. Expert Systems with Applications, 36(2), 1444-1458.

Tzeng, G. H., Chiang, C. H., \& Chung, W. L. (2007). Evaluating interwined effects in e-learning programs: A novel hybrid MCMD model based on factor analysis and DEMATEL. Expert Systems with Applications, 32(4), 1028-1044.

Winters, K. C., Stinchfield, R., \& Fulkerson, J. (1993). Patterns and characteristics of adolescent gambling. Journal of Gambling Studies, 9(4), 371-386. 